\title{
55. DATA REPORT: BULK SEDIMENT COMPOSITION AND MAGNETIC SUSCEPTIBILITY VARIATIONS IN HOLE 880A, TAKUYO-DAISAN GUYOT ${ }^{1}$
}

\author{
Frank R. Rack, ${ }^{2}$ Mont W. Lawyer, ${ }^{3}$ and Jeffrey S. Gee ${ }^{4}$
}

\begin{abstract}
Hole $880 \mathrm{~A}$ is located near the center of Takuyo-Daisan Guyot $\left(34^{\circ} 12.53^{\prime} \mathrm{N}, 144^{\circ} 18.74^{\prime} \mathrm{E}\right)$ at $1525 \mathrm{~m}$ water depth. Drilling at Hole $880 \mathrm{~A}$ recovered an 18.4-m-thick sequence of volcanic and biogenous pelagic sediment. The recovered sequence contains a condensed, but apparently complete, section spanning the entire Pleistocene and the Pleistocene/Pliocene boundary.

We present here the results of laboratory determinations of the weight percentage of calcium carbonate as well as the weight percentage of chemically extracted, fine-grained $(<63 \mathrm{~m})$ lithogenic material. Rapid, nondestructive measurements of magnetic susceptibility were made at high-field $(4.7 \mathrm{kHz})$ and low-field $(0.47 \mathrm{kHz})$ strengths. The magnetic measurements are used to investigate whether simple rock-magnetic parameters can contribute useful stratigraphic information in a marine environment where fine-grained ("eolian") sediments, either transported from Asia or derived from local sources of volcanic-rich sediments, are both contributing to the overall lithogenic flux.
\end{abstract}

\section{BACKGROUND AND OBJECTIVES}

\section{Geologic Setting}

Takuyo-Daisan Guyot is the easternmost guyot of the Seiko cluster in the Japanese Seamount province. It is located in the $30^{\circ}-35^{\circ} \mathrm{N}$ guyot band of the northwestern Pacific Ocean (see location map frontispiece) and lies on the M16 magnetic lineation (141-Ma crustal age; Nakanishi et al., 1992; Ozima et al., 1977; Vogt and Smoot, 1984).

SeaBeam data show that Takuyo-Daisan Guyot has a central volcano, which projects $110 \mathrm{~m}$ above the main summit level, and an outer ridge with an average height of $70 \mathrm{~m}$ above the encircled summit (van Waasbergen and Winterer, 1993). Small depressions infilled with pelagic sediment surround the central volcano. The slopes of the guyot are very steep $\left(\sim 21^{\circ}\right)$, and it has been suggested that they were constructed by small lava flows with a low effusive rate during the constructional volcanic phase of this seamount (Vogt and Smoot, 1984).

\section{Hole 880A}

Ocean Drilling Program (ODP) Hole $880 \mathrm{~A}$ is located at $34^{\circ} 12.53^{\prime} \mathrm{N}$, $144^{\circ} 18.74^{\prime} \mathrm{E}$ at $1525 \mathrm{~m}$ water depth, near the center of Takuyo-Daisan Guyot and about $2 \mathrm{nmi}$ north of Site 879 (Fig. 1). Drilling at Hole 880A recovered only two cores using the advanced hydraulic piston corer (APC), for a total penetration of $18.4 \mathrm{~m}$ below seafloor (mbsf). The Leg 144 shipboard sedimentologists identified one lithologic unit at this site, consisting of four different, interlayered lithologies. In order of decreasing abundance, these lithologies are (1) volcaniclastic sand, (2) foraminifer sand, (3) nannofossil-foraminifer ooze, and (4) volcanic ash (Premoli Silva, Haggerty, Rack, et al., 1993).

The sediment recovered in these cores ranges in color from shades of yellow-green and grayish brown to very dark gray. Increasing darkness is typically related to the increasing percentage of coarsegrained volcanic material, although light-colored volcanic ashes were also observed. Noncalcareous components include feldspars, opaques

\footnotetext{
${ }^{1}$ Haggerty, J.A., Premoli Silva, I., Rack, F., and McNutt, M.K. (Eds.), 1995. Proc. ODP, Sci. Results, 144: College Station, TX (Ocean Drilling Program).

Ocean Mapping Group. Department of Geodesy and Geomatics Engineering, University of New Brunswick, Fredericton, New Brunswick, Canada E3B 5A3.

${ }^{3}$ Department of Geology and Geophysics, Texas A\&M University, College Station, TX 77843, U.S.A.

${ }^{4}$ Lamont-Doherty Earth Observatory, Columbia University, Palisades, NY 10964.
}

(possibly manganese nodules), vesicular lava fragments, volcanic lapilli, scoriaceous basalt grains, and pyrite. Diatoms, sponge spicules, and silicoflagellates are frequent in the uppermost layers, but they decrease in abundance downhole (Premoli Silva, Haggerty, Rack, et al., 1993).

These pelagic sediments were deposited under the varying influence of volcanic eruptions from the nearby convergent margin setting and fluctuations in the degree of current winnowing (increased current strength would tend to remove the finer particles). The recovered sequence contains a condensed, but apparently complete, section spanning the entire Pleistocene and the Pleistocene/Pliocene boundary.

This report presents the results of laboratory determinations of the weight percentage of calcium carbonate, noncarbonate, and chemically extracted, fine-grained lithogenic material (volcanic and terrigenous) in samples at 10 -cm sample spacing throughout the $18.4 \mathrm{~m}$ of recovered core (Table 1 and Fig. 2$)$. Low-field $\left(0.47 \mathrm{kHz} ; \chi_{\mathrm{lf}}\right)$ and high-field $\left(4.7 \mathrm{kHz} ; \chi_{\mathrm{hf}}\right)$ magnetic susceptibility measurements were also made on each sample (Table 2 and Fig. 2).

Rock-magnetic parameters, including high-field and low-field susceptibility, have been used in many recent studies to investigate changes in the composition of marine sediments and to determine the relationships of these changes to the paleoclimatic record (Robinson, 1986; Doh et al., 1988; Bloemendal et al., 1988, 1993; among others). Ratios of individual magnetic parameters are independent of magnetic concentration and often reflect climate-related variations in the magnetic mineral assemblages.

The normalized field-dependent (frequency-dependent) susceptibility $\left(\chi_{\mathrm{fd}[\text { percent }]}=100\left[\chi_{\mathrm{lf}-} \chi_{\mathrm{hf}}\right] / \chi_{\mathrm{lf}}\right)$ is useful for detecting the presence of very fine ferrimagnetic grains, which are just below the stable single domain size (less than about $0.1 \mathrm{~m}$ for magnetite), and which show viscous magnetic properties (Thompson and Oldfield, 1982; Maher, 1986, 1988). The contribution of these very fine ferrimagnetic grains to susceptibility decreases as the frequency of the alternating field rises; hence, the $\chi_{\mathrm{fd}}$ percentage decreases with an increasing proportion of these grains.

Plots of low-field magnetic susceptibility and sediment compositional data are compared with black-and-white (gray-scale) photographs of individual core sections to explore the correspondence between downhole changes in sediment color and observed trends (gradients) in bulk sediment composition (e.g., weight percentage of calcium carbonate, lithogenic sand [ $>63 \mathrm{~m}]$ fraction, and the lithogenic silt/clay or "eolian" $[<63 \mathrm{~m}]$ fraction of the bulk sediment) and magnetic susceptibility. It remains to be seen whether the fielddependent susceptibility can be used as an indicator of the changes in grain size and volcanic ash in these sediments. 
Table 1. Results of calcium carbonate determinations and chemical extractions of lithogenic material, Hole $880 \mathrm{~A}$.

\begin{tabular}{|c|c|c|c|c|c|c|}
\hline $\begin{array}{l}\text { Core, section, } \\
\text { interval }(\mathrm{cm})\end{array}$ & $\begin{array}{l}\text { Depth } \\
\text { (mbsf) }\end{array}$ & $\begin{array}{l}\mathrm{CaCO}_{3} \\
(\mathrm{wt} \%)\end{array}$ & $\begin{array}{l}\text { Noncarbonate } \\
(w t \%)\end{array}$ & $\begin{array}{l}\text { NC-Eolian } \\
\text { (wt\%) }\end{array}$ & $\begin{array}{l}\text { Eolian } \\
\text { (wt\%) }\end{array}$ & $\begin{array}{l}\text { \%Eolian } \\
\text { carb-free }\end{array}$ \\
\hline \multicolumn{7}{|l|}{ 144-880A- } \\
\hline $1 \mathrm{H}-1,0-2$ & 0.00 & 22.27 & 77.73 & 70.72 & 7.01 & 9.01 \\
\hline $\mathrm{IH}-1,10-12$ & 0.10 & 47.40 & 52.60 & 44.49 & 8.11 & 15.41 \\
\hline $1 \mathrm{H}-1,20-22$ & 0.20 & 34.71 & 65.29 & 52.37 & 12.92 & 19.79 \\
\hline $1 \mathrm{H}-1,30-32$ & 0.30 & 31.53 & 68.47 & 54.75 & 13.72 & 20.04 \\
\hline $1 \mathrm{H}-1,40-42$ & 0.40 & 38.03 & 61.97 & 51.71 & 10.26 & 16.56 \\
\hline $1 \mathrm{H}-1,50-52$ & 0.50 & 26.59 & 73.41 & 59.03 & 14.38 & 19.58 \\
\hline $1 \mathrm{H}-1,59-61$ & 0.59 & 29.83 & 70.17 & 56.72 & 13.45 & 19.17 \\
\hline $1 \mathrm{H}-1,70-72$ & 0.70 & 32.12 & 67.88 & 53.42 & 14.46 & 21.31 \\
\hline $1 \mathrm{H}-1,81-83$ & 0.81 & 10.98 & 89.02 & 75.25 & 13.77 & 15.47 \\
\hline $1 \mathrm{H}-1,90-92$ & 0.90 & 11.53 & 88.47 & 71.48 & 16.99 & 19.21 \\
\hline $1 \mathrm{H}-1,100-102$ & 1.00 & 8.92 & 91.08 & 81.32 & 9.76 & 10.71 \\
\hline $1 \mathrm{H}-1,110-112$ & 1.10 & 8.14 & 91.86 & 80.58 & 11.28 & 12.28 \\
\hline $1 \mathrm{H}-1,120-122$ & 1.20 & 6.75 & 93.25 & 84.12 & 9.13 & 9.79 \\
\hline $1 \mathrm{H}-1,130-132$ & 1.30 & 27.59 & 72.41 & 62.28 & 10.13 & 13.98 \\
\hline $1 \mathrm{H}-1,140-142$ & 1.40 & 36.12 & 63.88 & 58.23 & 5.65 & 8.85 \\
\hline $1 \mathrm{H}-2,1-3$ & 1.51 & 44.49 & 55.51 & 43.29 & 12.22 & 22.02 \\
\hline $1 \mathrm{H}-2,10-12$ & 1.60 & 33.34 & 66.66 & 51.66 & 15.00 & 22.51 \\
\hline $1 \mathrm{H}-2,20-22$ & 1.70 & 24.21 & 75.79 & 60.29 & 15.50 & 20.45 \\
\hline $1 \mathrm{H}-2,30-32$ & 1.80 & 47.84 & 52.16 & 41.65 & 10.51 & 20.14 \\
\hline $1 \mathrm{H}-2,38-40$ & 1.88 & 33.67 & 66.33 & 53.73 & 12.60 & 18.99 \\
\hline $1 \mathrm{H}-2,50-52$ & 2.00 & 21.37 & 78.63 & 62.84 & 15.79 & 20.08 \\
\hline $1 \mathrm{H}-2,61-63$ & 2.11 & 21.83 & 78.17 & 61.90 & 16.27 & 20.82 \\
\hline $1 \mathrm{H}-2,68-70$ & 2.18 & 24.13 & 75.87 & 65.44 & 10.43 & 13.74 \\
\hline $1 \mathrm{H}-2,80-82$ & 2.30 & 8.15 & 91.85 & 81.93 & 9.92 & 10.80 \\
\hline $1 \mathrm{H}-2,90-92$ & 2.40 & 3.60 & 96.40 & 78.25 & 18.15 & 18.82 \\
\hline $\mathrm{IH}-2,100-102$ & 2.50 & 4.68 & 95.32 & 85.06 & 10.26 & 10.77 \\
\hline $1 \mathrm{H}-2,110-112$ & 2.60 & 3.48 & 96.52 & 83.45 & 13.07 & 13.55 \\
\hline $1 \mathrm{H}-2,119-121$ & 2.69 & 0.00 & 100.00 & 88.90 & 11.10 & 11.10 \\
\hline $\mathrm{IH}-2,130-132$ & 2.80 & 13.37 & 86.63 & 72.72 & 13.91 & 16.05 \\
\hline IH-2, $140-142$ & 2.90 & 4.60 & 95.40 & 81.89 & 13.51 & 14.16 \\
\hline IH-3, $1-3$ & 3.01 & 18.33 & 81.67 & 70.16 & 11.51 & 14.09 \\
\hline $1 \mathrm{H}-3,10-12$ & 3.10 & 33.25 & 66.75 & 55.57 & 11.18 & 16.76 \\
\hline IH-3, 20-22 & 3.20 & 32.24 & 67.76 & 55.00 & 12.76 & 18.83 \\
\hline IH $-3,30-32$ & 3.30 & 27.77 & 72.23 & 60.45 & 11.78 & 16.30 \\
\hline IH $-3,40-42$ & 3.40 & 11.60 & 88.40 & 73.93 & 14.47 & 16.37 \\
\hline IH-3, 51-53 & 3.51 & 6.97 & 93.03 & 66.80 & 26.23 & 28.20 \\
\hline IH-3, 59-61 & 3.59 & 19.57 & 80.43 & 70.00 & 10.43 & 12.96 \\
\hline IH-3, 71-73 & 3.71 & 7.75 & 92.25 & 81.90 & 10.35 & 11.21 \\
\hline IH-3, 78-80 & 3.78 & 6.97 & 93.03 & 83.39 & 9.64 & 10.36 \\
\hline IH-3, 90-92 & 3.90 & 27.88 & 72.12 & 60.68 & 11.44 & 15.86 \\
\hline $1 \mathrm{H}-3,100-102$ & 4.00 & 30.95 & 69.05 & 58.59 & 10.46 & 15.15 \\
\hline $1 \mathrm{H}-3,110-112$ & 4.10 & 18.16 & 81.84 & 69.76 & 12.08 & 14.76 \\
\hline IH-3, 118-120 & 4.18 & 15.18 & 84.82 & 69.00 & 15.82 & 18.65 \\
\hline $1 \mathrm{H}-3,130-132$ & 4.30 & 8.93 & 91.07 & 79.77 & 11.30 & 12.41 \\
\hline IH-3, 140-142 & 4.40 & 7.22 & 92.78 & 80.98 & 11.80 & 12,71 \\
\hline IH-4, 0-2 & 4.50 & 19.73 & 80.27 & 70.01 & 10.26 & 12.79 \\
\hline IH-4, $10-12$ & 4.60 & 36.00 & 64.00 & 54.98 & 9.02 & 14.09 \\
\hline $1 \mathrm{H}-4,20-22$ & 4.70 & 30.96 & 69.04 & 59.93 & 9.11 & 13.20 \\
\hline IH $-4,30-32$ & 4.80 & 32.35 & 67.65 & 56.06 & 11.59 & 17.13 \\
\hline $1 \mathrm{H}-4,40-42$ & 4.90 & 32.46 & 67.54 & 58.12 & 9.42 & 13.94 \\
\hline $1 \mathrm{H}-4,48-50$ & 4.98 & 35.34 & 64.66 & 49.65 & 15.01 & 23.21 \\
\hline $1 \mathrm{H}-4,60-62$ & 5.10 & 15.37 & 84.63 & 67.10 & 17.53 & 20.72 \\
\hline $1 \mathrm{H}-4,70-72$ & 5.20 & 17.66 & 82.34 & 69.08 & 13.26 & 16.10 \\
\hline IH- $4,80-82$ & 5.30 & 15.94 & 84.06 & 67.23 & 16.83 & 20.02 \\
\hline $1 \mathrm{H}-4,90-92$ & 5.40 & 10.80 & 89.20 & 77.25 & 11.95 & 13.40 \\
\hline $1 \mathrm{H}-4,98-100$ & 5.48 & 28.55 & 71.45 & 59.58 & 11.87 & 16.61 \\
\hline $1 \mathrm{H}-4,110-112$ & 5.60 & 31.54 & 68.46 & 56.53 & 11.93 & 17.42 \\
\hline $1 \mathrm{H}-4,120-122$ & 5.70 & 15.77 & 84.23 & 67.45 & 16.78 & 19.92 \\
\hline $1 \mathrm{H}-4,130-132$ & 5.80 & 22.93 & 77.07 & 59.91 & 17.16 & 22.26 \\
\hline $1 \mathrm{H}-4,138-140$ & 5.88 & 34.76 & 65.24 & 54.51 & 10.73 & 16.45 \\
\hline $1 \mathrm{H}-5, \mathrm{I}-3$ & 6.01 & 18.02 & 81.98 & 61.23 & 20.75 & 25.31 \\
\hline $1 \mathrm{H}-5,10-12$ & 6.10 & 10.65 & 89.35 & 60.52 & 28.83 & 32.27 \\
\hline $1 \mathrm{H}-5,19-21$ & 6.19 & 14.72 & 85.28 & 64.82 & 20.46 & 23.99 \\
\hline IH-5, 30-32 & 6.30 & 9.45 & 90.55 & 60.33 & 30.22 & 33.37 \\
\hline $1 \mathrm{H}-5,39-41$ & 6.39 & 5.49 & 94.51 & 70.06 & 24.45 & 25.87 \\
\hline IH $-5,50-52$ & 6.50 & 18.44 & 81.56 & 67.89 & 13.67 & 16.77 \\
\hline $1 \mathrm{H}-5,59-61$ & 6.59 & 13.94 & 86.06 & 67.18 & 18.88 & 21.94 \\
\hline $1 \mathrm{H}-5,70-72$ & 6.70 & 9.17 & 90.83 & 74.75 & 16.08 & 17.70 \\
\hline $1 \mathrm{H}-5,80-82$ & 6.80 & 46.25 & 53.75 & 44.41 & 9.34 & 17.38 \\
\hline $1 \mathrm{H}-5,90-92$ & 6.90 & 0.00 & 100.00 & 83.93 & 16.07 & 16.07 \\
\hline $1 \mathrm{H}-5,98-100$ & 6.98 & 48.46 & 51.54 & 38.06 & 13.48 & 26.15 \\
\hline $1 \mathrm{H}-5,110-112$ & 7.10 & 43.95 & 56.05 & 42.33 & 13.72 & 24.47 \\
\hline $\mathrm{IH}-5,120-122$ & 7.20 & 42.83 & 57.17 & 42.17 & 15.00 & 26.24 \\
\hline $1 \mathrm{H}-5,130-132$ & 7.30 & 42.80 & 57.20 & 42.13 & 15.07 & 26.35 \\
\hline $1 \mathrm{H}-5,140-142$ & 7.40 & 27.24 & 72.76 & 53.07 & 19.69 & 27.06 \\
\hline IH-6, 0-2 & 7.50 & 18.91 & 81.09 & 65.02 & 16.07 & 19.82 \\
\hline $1 \mathrm{H}-6,10-12$ & 7.60 & 38.11 & 61.89 & 44.99 & 16.90 & 27.30 \\
\hline $1 \mathrm{H}-6,20-22$ & 7.70 & 25.63 & 74.37 & 55.72 & 18.65 & 25.07 \\
\hline IH-6, 30-32 & 7.80 & 32.11 & 67.89 & 54.07 & 13.82 & 20.35 \\
\hline IH- $6,40-42$ & 7.90 & 0.00 & 100.00 & 54.78 & 45.22 & 45.22 \\
\hline IH- $6,48-50$ & 7.98 & 23.71 & 76.29 & 60.10 & 16.19 & 21.22 \\
\hline IH-6, 60-62 & 8.10 & 8.32 & 91.68 & 69.07 & 22.61 & 24.66 \\
\hline $1 \mathrm{H}-6,71-73$ & 8.20 & 6.15 & 93.85 & 80.08 & 13.77 & 14.67 \\
\hline IH-6, 80-82 & 8.30 & 29.69 & 70.31 & 59.26 & 11.05 & 15.71 \\
\hline IH-6, 90-92 & 8.40 & 27.85 & 72.15 & 59.05 & 13.10 & 18.16 \\
\hline $1 \mathrm{H}-6,100-102$ & 8.50 & 22.65 & 77.35 & 54.33 & 23.02 & 29.77 \\
\hline $1 \mathrm{H}-6,110-112$ & 8.60 & 25.63 & 74.37 & 53.04 & 21.33 & 28.68 \\
\hline $2 \mathrm{H}-1,5-7$ & 8.95 & 14.23 & 85.77 & 73.53 & 12.24 & 14.27 \\
\hline
\end{tabular}


Table 1 (continued).

\begin{tabular}{|c|c|c|c|c|c|c|}
\hline $\begin{array}{l}\text { Core, section, } \\
\text { interval }(\mathrm{cm})\end{array}$ & $\begin{array}{l}\text { Depth } \\
\text { (mbsf) }\end{array}$ & $\begin{array}{l}\mathrm{CaCO}_{3} \\
(\mathrm{wt} \%)\end{array}$ & $\begin{array}{c}\text { Noncarbonate } \\
(\mathrm{wt} \%)\end{array}$ & $\begin{array}{l}\text { NC-Eolian } \\
\text { (wt } \%)\end{array}$ & $\begin{array}{l}\text { Eolian } \\
\text { (wt\%) }\end{array}$ & $\begin{array}{l}\text { \%Eolian } \\
\text { carb-free }\end{array}$ \\
\hline $2 \mathrm{H}-1,11-13$ & 9.01 & 14.16 & 85.84 & 63.30 & 22.54 & 26.26 \\
\hline $2 \mathrm{H}-1,20-22$ & 9.10 & 38.45 & 61.55 & 41.49 & 20.06 & 32.60 \\
\hline $2 \mathrm{H}-1,29-31$ & 9.19 & 45.90 & 54.10 & 32.78 & 21.32 & 39.41 \\
\hline $2 \mathrm{H}-1,40-42$ & 9.30 & 32.11 & 67.89 & 41.75 & 26.14 & 38.50 \\
\hline $2 \mathrm{H}-1,50-52$ & 9.40 & 34.93 & 65.07 & 42.49 & 22.58 & 34.69 \\
\hline $2 \mathrm{H}-1,59-61$ & 9.49 & 27.10 & 72.90 & 48.31 & 24.59 & 33.73 \\
\hline $2 \mathrm{H}-1,7 \mathrm{I}-73$ & 9.61 & 32.20 & 67.80 & 42.66 & 25.14 & 37.08 \\
\hline $2 \mathrm{H}-1,80-82$ & 9.70 & 16.76 & 83.24 & 55.62 & 27.62 & 33.18 \\
\hline $2 \mathrm{H}-1,90-92$ & 9.80 & 15.42 & 84.58 & 66.33 & 18.25 & 21.58 \\
\hline $2 \mathrm{H}-1,100-102$ & 9.90 & 28.92 & 71.08 & 52.44 & 18.64 & 26.23 \\
\hline $2 \mathrm{H}-1,110-112$ & 10.00 & 35.12 & 64.88 & 49.12 & 15.76 & 24.29 \\
\hline $2 \mathrm{H}-1,120-122$ & 10.10 & 14.04 & 85.96 & 72.81 & 13.15 & 15.30 \\
\hline $2 \mathrm{H}-1,130-132$ & 10.20 & 13.33 & 86.67 & 73.69 & 12.98 & 14.98 \\
\hline $2 \mathrm{H}-2,0-2$ & 10.27 & 14.15 & 85.85 & 69.95 & 15.90 & 18.52 \\
\hline $2 \mathrm{H}-2,10-12$ & 10.37 & 15.25 & 84.75 & 71.59 & 13.16 & 15.53 \\
\hline $2 \mathrm{H}-2,20-22$ & 10.47 & 38.05 & 61.95 & 48.56 & 13.39 & 21.61 \\
\hline $2 \mathrm{H}-2,27-29$ & 10.54 & 31.30 & 68.70 & 55.06 & 13.64 & 19.86 \\
\hline $2 \mathrm{H}-2,40-42$ & 10.67 & 23.14 & 76.86 & 55.78 & 21.08 & 27.43 \\
\hline $2 \mathrm{H}-2,50-52$ & 10.77 & 38.93 & 61.07 & 45.38 & 15.69 & 25.70 \\
\hline $2 \mathrm{H}-2,57-59$ & 10.84 & 26.11 & 73.89 & 55.78 & 18.11 & 24.51 \\
\hline $2 \mathrm{H}-2,70-72$ & 10.97 & 13.01 & 86.99 & 71.10 & 15.89 & 18.26 \\
\hline $2 \mathrm{H}-2,77-79$ & 11.04 & 17.82 & 82.18 & 63.29 & 18.89 & 22.98 \\
\hline $2 \mathrm{H}-2,90-92$ & 11.17 & 26.01 & 73.99 & 60.70 & 13.29 & 17.96 \\
\hline $2 \mathrm{H}-2,100-102$ & 11.27 & 18.25 & 81.75 & 63.12 & 18.63 & 22.78 \\
\hline $2 \mathrm{H}-2,110-112$ & 11.37 & 9.14 & 90.86 & 71.64 & 19.22 & 21.15 \\
\hline $2 \mathrm{H}-2,120-122$ & 11.47 & 15.88 & 84.12 & 69.79 & 14.33 & 17.04 \\
\hline $2 \mathrm{H}-2,132-134$ & 11.59 & 26.82 & 73.18 & 58.38 & 14.80 & 20.22 \\
\hline $2 \mathrm{H}-2,140-142$ & 11.67 & 24.72 & 75.28 & 63.37 & 11.91 & 15.82 \\
\hline $2 \mathrm{H}-3,1-3$ & 11.78 & 19.39 & 80.61 & 66.29 & 14.32 & 17.77 \\
\hline $2 \mathrm{H}-3,10-12$ & 11.87 & 13.39 & 86.61 & 75.19 & 11.42 & 13.19 \\
\hline $2 \mathrm{H}-3,20-22$ & 11.97 & 16.74 & 83.26 & 72.42 & 10.84 & 13.01 \\
\hline $2 \mathrm{H}-3,27-29$ & 12.04 & 12.55 & 87.45 & 79.05 & 8.40 & 9.61 \\
\hline $2 \mathrm{H}-3,40-42$ & 12.17 & 12.44 & 87.56 & 75.77 & 11.79 & 13.46 \\
\hline $2 \mathrm{H}-3,50-52$ & 12.27 & 16.01 & 83.99 & 75.73 & 8.26 & 9.84 \\
\hline $2 \mathrm{H}-3,58-60$ & 12.35 & 15.22 & 84.78 & 69.77 & 15.01 & 17.71 \\
\hline $2 \mathrm{H}-3,70-72$ & 12.47 & 12.99 & 87.01 & 77.55 & 9.46 & 10.87 \\
\hline $2 \mathrm{H}-3,80-82$ & 12.57 & 28.28 & 71.72 & 58.95 & 12.77 & 17.81 \\
\hline $2 \mathrm{H}-3,90-92$ & 12.67 & 24.50 & 75.50 & 66.11 & 9.39 & 12.43 \\
\hline $2 \mathrm{H}-3,97-99$ & 12.74 & 11.87 & 88.13 & 72.87 & 15.26 & 17.32 \\
\hline $2 \mathrm{H}-3,110-112$ & 12.87 & 8.60 & 91.40 & 71.87 & 19.53 & 21.37 \\
\hline $2 \mathrm{H}-3,120-122$ & 12.97 & 31.44 & 68.56 & 62.23 & 6.33 & 9.23 \\
\hline $2 \mathrm{H}-3,130-132$ & 13.07 & 17.21 & 82.79 & 68.05 & 14.74 & 17.80 \\
\hline $2 \mathrm{H}-3,140-142$ & 13.17 & 11.27 & 88.73 & 71.57 & 17.16 & 19.34 \\
\hline $2 \mathrm{H}-4,0-2$ & 13.27 & 14.53 & 85.47 & 68.44 & 17.03 & 19.93 \\
\hline $2 \mathrm{H}-4,10-12$ & 13.37 & 24.63 & 75.37 & 62.28 & 13.09 & 17.37 \\
\hline $2 \mathrm{H}-4,20-22$ & 13.47 & 24.77 & 75.23 & 61.85 & 13.38 & 17.78 \\
\hline $2 \mathrm{H}-4,30-32$ & 13.57 & 21.10 & 78.90 & 60.06 & 18.84 & 23.88 \\
\hline $2 \mathrm{H}-4,40-42$ & 13.67 & 38.72 & 61.28 & 47.30 & 13.98 & 22.81 \\
\hline $2 \mathrm{H}-4,50-52$ & 13.77 & 17.77 & 82.23 & 67.03 & 15.20 & 18.49 \\
\hline $2 \mathrm{H}-4,57-59$ & 13.84 & 10.05 & 89.95 & 79.72 & 10.23 & 11.37 \\
\hline $2 \mathrm{H}-4,72-74$ & 13.99 & 21.09 & 78.91 & 68.19 & 10.72 & 13.59 \\
\hline $2 \mathrm{H}-4,80-82$ & 14.07 & 17.50 & 82.50 & 70.55 & 11.95 & 14.48 \\
\hline $2 \mathrm{H}-4,90-92$ & 14.17 & 10.60 & 89.40 & 72.04 & 17.36 & 19.42 \\
\hline $2 \mathrm{H}-4,100-102$ & 14.27 & 4.80 & 95.20 & 74.31 & 20.89 & 21.94 \\
\hline $2 \mathrm{H}-4,110-112$ & 14.37 & 32.51 & 67.49 & 50.42 & 17.07 & 25.29 \\
\hline $2 \mathrm{H}-4,120-122$ & 14.47 & 23.43 & 76.57 & 63.83 & 12.74 & 16.64 \\
\hline $2 \mathrm{H}-4,130-132$ & 14.57 & 30.74 & 69.26 & 57.56 & 11.70 & 16.89 \\
\hline $2 \mathrm{H}-4,140-142$ & 14.67 & 27.18 & 72.82 & 59.02 & 13.80 & 18.95 \\
\hline $2 \mathrm{H}-5,0-2$ & 14.77 & 12.35 & 87.65 & 71.85 & 15.80 & 18.03 \\
\hline $2 \mathrm{H}-5,10-12$ & 14.87 & 9.43 & 90.57 & 69.88 & 20.69 & 22.85 \\
\hline $2 \mathrm{H}-5,20-22$ & 14.97 & 27.57 & 72.43 & 56.29 & 16.14 & 22.28 \\
\hline $2 \mathrm{H}-5,30-32$ & 15.07 & 18.63 & 81.37 & 69.64 & 11.73 & 14.42 \\
\hline $2 \mathrm{H}-5,40-42$ & 15.17 & 16.81 & 83.19 & 70.18 & 13.01 & 15.64 \\
\hline $2 \mathrm{H}-5,50-52$ & 15.27 & 12.91 & 87.09 & 66.27 & 20.82 & 23.90 \\
\hline $2 \mathrm{H}-5,62-64$ & 15.39 & 12.27 & 87.73 & 74.98 & 12.75 & 14.53 \\
\hline $2 \mathrm{H}-5,72-74$ & 15.49 & 22.39 & 77.61 & 65.18 & 12.43 & 16.02 \\
\hline $2 \mathrm{H}-5,80-82$ & 15.57 & 11.84 & 88.16 & 72.25 & 15.91 & 18.05 \\
\hline $2 \mathrm{H}-5,88-90$ & 15.65 & 1.52 & 98.48 & 60.16 & 38.32 & 38.92 \\
\hline $2 \mathrm{H}-5,100-102$ & 15.77 & 22.43 & 77.57 & 65.34 & 12.23 & 15.77 \\
\hline $2 \mathrm{H}-5,109-111$ & 15.86 & 13.22 & 86.78 & 66.62 & 20.16 & 23.23 \\
\hline $2 \mathrm{H}-5,120-122$ & 15.97 & 27.67 & 72.33 & 59.87 & 12.46 & 17.23 \\
\hline $2 \mathrm{H}-5,129-131$ & 16.06 & 25.75 & 74.25 & 53.75 & 20.50 & 27.61 \\
\hline $2 \mathrm{H}-5,136-138$ & 16.13 & 30.92 & 69.08 & 52.62 & 16.46 & 23.83 \\
\hline $2 \mathrm{H}-6,0-2$ & 16.27 & 19.26 & 80.74 & 64.96 & 15.78 & 19.55 \\
\hline $2 \mathrm{H}-6,10-12$ & 16.37 & 27.77 & 72.23 & 61.17 & 11.06 & 15.31 \\
\hline $2 \mathrm{H}-6,20-22$ & 16.47 & 22.63 & 77.37 & 57.61 & 19.76 & 25.53 \\
\hline $2 \mathrm{H}-6,30-32$ & 16.57 & 18.49 & 81.51 & 59.87 & 21.64 & 26.54 \\
\hline $2 \mathrm{H}-6,40-42$ & 16.67 & 35.56 & 64.44 & 48.68 & 15.76 & 24.46 \\
\hline $2 \mathrm{H}-6,50-52$ & 16.77 & 31.98 & 68.02 & 52.79 & 15.23 & 22.38 \\
\hline $2 \mathrm{H}-6,60-62$ & 16.87 & 21.36 & 78.64 & 64.33 & 14.31 & 18.20 \\
\hline $2 \mathrm{H}-6,69-71$ & 16.96 & 12.61 & 87.39 & 73.88 & 13.51 & 15.46 \\
\hline $2 \mathrm{H}-6,81-83$ & 17.08 & 15.64 & 84.36 & 68.52 & 15.84 & 18.77 \\
\hline $2 \mathrm{H}-6,90-92$ & 17.17 & 18.77 & 81.23 & 68.75 & 12.48 & 15.37 \\
\hline $2 \mathrm{H}-6,97-99$ & 17.24 & 17.19 & 82.81 & 71.39 & 11.42 & 13.79 \\
\hline $2 \mathrm{H}-6,110-112$ & 17.37 & 16.40 & 83.60 & 69.39 & 14.21 & 17.00 \\
\hline $2 \mathrm{H}-6,120-122$ & 17.47 & 16.58 & 83.42 & 64.58 & 18.84 & 22.59 \\
\hline $2 \mathrm{H}-6,130-132$ & 17.57 & 18.41 & 81.59 & 55.14 & 26.45 & 32.42 \\
\hline $2 \mathrm{H}-6,139-141$ & 17.66 & 24.18 & 75.82 & 65.47 & 10.35 & 13.65 \\
\hline $2 \mathrm{H}-7,0-2$ & 17.77 & 22.70 & 77.30 & 66.44 & 10.86 & 14.05 \\
\hline
\end{tabular}


Table 1 (continued).

\begin{tabular}{lcccccc}
\hline $\begin{array}{c}\text { Core, section, } \\
\text { interval }(\mathrm{cm})\end{array}$ & $\begin{array}{c}\text { Depth } \\
\text { (mbsf) }\end{array}$ & $\begin{array}{c}\mathrm{CaCO}_{3} \\
\text { (wt\%) }\end{array}$ & $\begin{array}{c}\text { Noncarbonate } \\
\text { (wt\%) }\end{array}$ & $\begin{array}{c}\text { NC-Eolian } \\
\text { (wt\%) }\end{array}$ & $\begin{array}{c}\text { Eolian } \\
\text { (wt\%) }\end{array}$ & $\begin{array}{c}\text { \%Eolian } \\
\text { carb-free }\end{array}$ \\
\hline $2 \mathrm{H}-7,10-12$ & 17.87 & 21.95 & 78.05 & 63.04 & 15.01 & 19.23 \\
$2 \mathrm{H}-7,20-22$ & 17.97 & 26.62 & 73.38 & 55.34 & 18.04 & 24.59 \\
$2 \mathrm{H}-7,30-32$ & 18.07 & 9.99 & 90.01 & 70.67 & 19.34 & 21.49 \\
$2 \mathrm{H}-7,40-42$ & 18.17 & 11.86 & 88.14 & 74.02 & 14.12 & 16.02 \\
$2 \mathrm{H}-7,52-54$ & 18.29 & 23.83 & 76.17 & 58.95 & 17.22 & 22.61 \\
\hline
\end{tabular}

Notes: $\mathrm{CaCO}_{3}=$ percentage of calcium carbonate in bulk sample: Noncarbonate = percentage of noncarbonate in bulk sample (calculated as $100 \%$ - wt $\% \mathrm{CaCO}$ in bulk sample); $\mathrm{NC}_{-}$ Eolian = percentage of noncarbonate in bulk sample minus percentage of the extracted "eolian," or fine-grained $(<63 \mu \mathrm{m})$ lithogenic fraction; Eolian $=$ percentage of the extracted "eolian" fraction of the bulk sample; \%Eolian (carb-free) = weight percentage of the extracted "eolian" fraction relative to the noncarbonate weight percentage rather than to the total bulk sample.

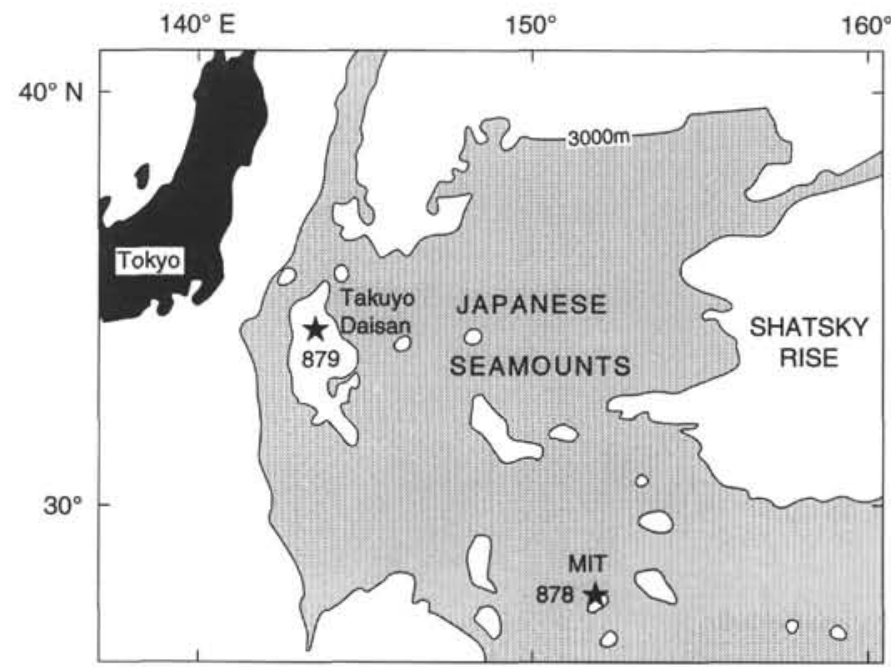

Figure 1. Location map showing the position of Takuyo-Daisan Guyot in the Japanese Seamounts relative to Shatsky Rise and Site 879 . Hole $880 \mathrm{~A}$ is located about 2 nmi north of Site 879 .

\section{METHODS}

The sediment samples that were used in this study were initially collected by ODP technicians from the working-half of the cores stored in the ODP Gulf Coast Repository in College Station, Texas. The individual samples were removed from the split-core in an oriented, 6- $\mathrm{cm}^{3}$, paleomagnetic cube at a sample spacing of $10 \mathrm{~cm}$.

The samples were first sent to Lamont-Doherty Earth Observatory where they were used to remeasure the paleomagnetic properties of the sediments after stepwise alternating-field (AF) demagnetization. Shipboard measurements had indicated that the sediments were completely remagnetized during the drilling/coring process. Hole $880 \mathrm{~A}$ was cored after the drill string underwent a "magnaflux" treatment near the conclusion of Leg 144. Post-cruise measurements of the intensity of natural remanent magnetization (NRM) of these samples are given in Table 2. Magnetic polarity reversal boundaries are given in Table 3 and are illustrated in Figure 2. Following the completion of these magnetic measurements, smear slides of each sample were made at the University of Milan so as to develop the detailed nannofossil biostratigraphy of this hole (see Erba, this volume).

The samples were then sent to Texas A\&M University, where they were weighed and used to measure the low-field $\left(\chi_{\mathrm{lf}}\right)$ susceptibility at $0.47 \mathrm{kHz}$, and the high-field $\left(\chi_{\mathrm{hf}}\right)$ susceptibility at $4.7 \mathrm{kHz}$, using a Bartington Model MS-2 susceptibility meter attached to a $36-\mathrm{mm}$ loop. Discrete measurements were made at constant settings $(0.1$ scale $=10 \mathrm{~s}$; low-field); the meter has a sensitivity on the order of $10^{-8} \mathrm{~m}^{3} / \mathrm{kg}$. After the magnetic measurements were concluded, the samples were freeze-dried, weighed, and then used for further chemical analyses.

The inorganic carbon content of each sample was determined using a Coulometrics carbon dioxide coulometer. Ten to twenty mg, freeze-dried and weighed samples were reacted in $2 \mathrm{~N} \mathrm{HCl}$ solution at $60^{\circ} \mathrm{C}$. Evolved carbon dioxide was titrated in a monoethanolamide solution with a coulometric indicator over a period of 5-20 min depending on the carbonate reactivity. Calibration was performed using pure calcium carbonate as a standard. The weight percentage of carbonate was calculated from the inorganic carbon (IC) content, assuming that all carbonate was in the form of calcite (weight percentage of $\mathrm{CaCO}_{3}=\% \mathrm{IC} \times 8.33$ ).

After the determination of inorganic carbon, the remaining portion of each sample from Hole 880A was weighed and processed according to a lithogenic extraction procedure, as described in Rea and Janecek (1981) and in the appendix to Clemens and Prell (1990).

The lithogenic component of the bulk sediment (including contributions from both terrigenous and volcanic sources) was isolated by a series of selective extractions to remove calcium carbonate, opaline silica, Fe and Mn oxides, and hydroxides and zeolites. The material passing through a $<63-\mathrm{m}$ sieve after the completion of the extraction procedure was weighed to determine the fine-grained lithogenic or "eolian" $(<63 \mathrm{~m})$ weight percentage of the total sample. Throughout this paper, the term "eolian" is used to refer to the extracted silt + clay-sized fraction (lithogenic material $<63 \mathrm{~m}$ ) of the bulk samples; the use of this term is a standard convention and does not necessarily indicate the transport mechanism or origin of this material. In general, the fine-grained lithogenic fraction of samples from Hole $880 \mathrm{~A}$ was dominated by clays, fine-grained quartz, and opaque grains of probable volcanic origin.

The coarse-grained lithogenic fraction of the extracted material was retained by the $<63-\mathrm{m}$ sieve. Unfortunately, the coarse-grained material from each sample was not saved for further visual analysis. This mistake in processing these samples precludes at present a more detailed discussion of the volcanic components of the coarse-grained lithogenic sediment in this hole. Smear slides of the fine-grained lithogenic material from each sample have also not been made at this time. These slides could be used to estimate the amount of volcanic material in the silt + clay-sized lithogenic fraction of each sample.

\section{DISCUSSION OF RESULTS}

The cores recovered from Hole $880 \mathrm{~A}$ exhibit an array of color changes; variations in the percentages of biogenous, volcanic, and terrigenous components; fluctuations in grain size; and variations in rock-magnetic parameters. The data from laboratory measurements made on samples from Hole 880A are given in Tables 1 and 2 and illustrated in Figure 2. The general trends in the data show subtle differences in the amplitude and frequency of property fluctuations above and below $\sim 9 \mathrm{mbsf}$. The specific relationships between the fluctuations in rock-magnetic properties and changes in bulk sediment composition are complex. The purpose of the remainder of this discussion is to identify the observed variations in lithology, sediment color, and lowfield magnetic susceptibility for specific horizons in Hole 880A.

In Figures 3 through 14, photographs of individual $1.5-\mathrm{m}$ core sections are presented along with plots of (1) low-field magnetic susceptibility; (2) sediment composition (as cumulative weight percentage [wt $\%$ plots of, from left to right, wt\%-calcium carbonate, 


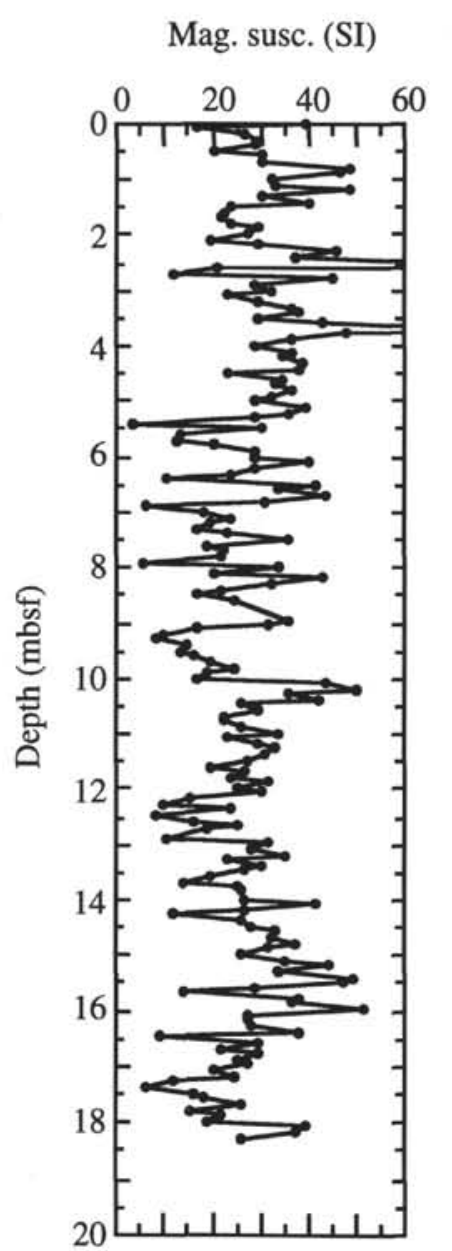

Composition (\%)

0

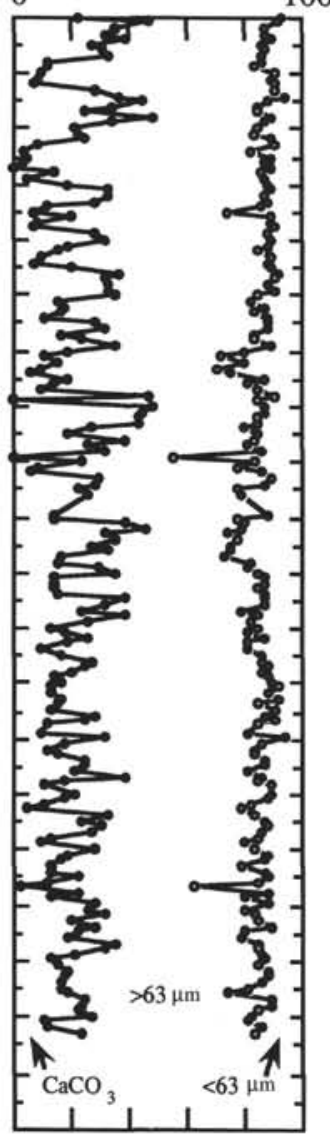

Lithogenic $\%$-silt+clay $/ \%$-sand
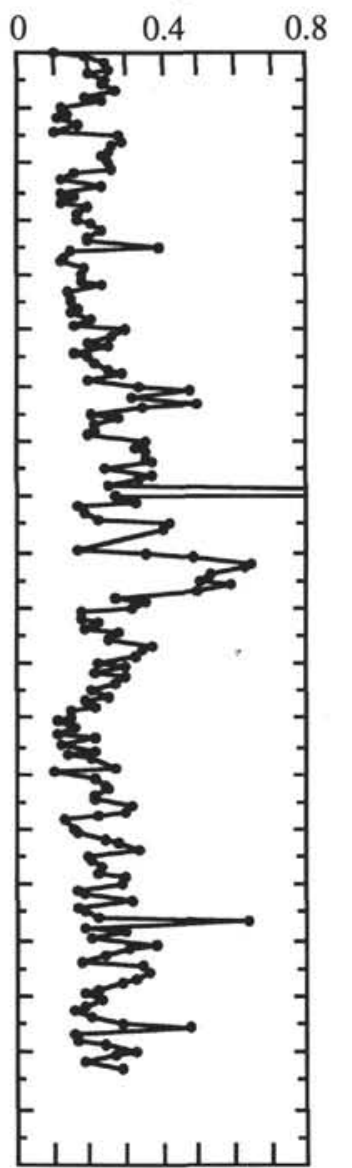

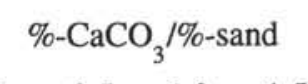

Mag.

Pol.

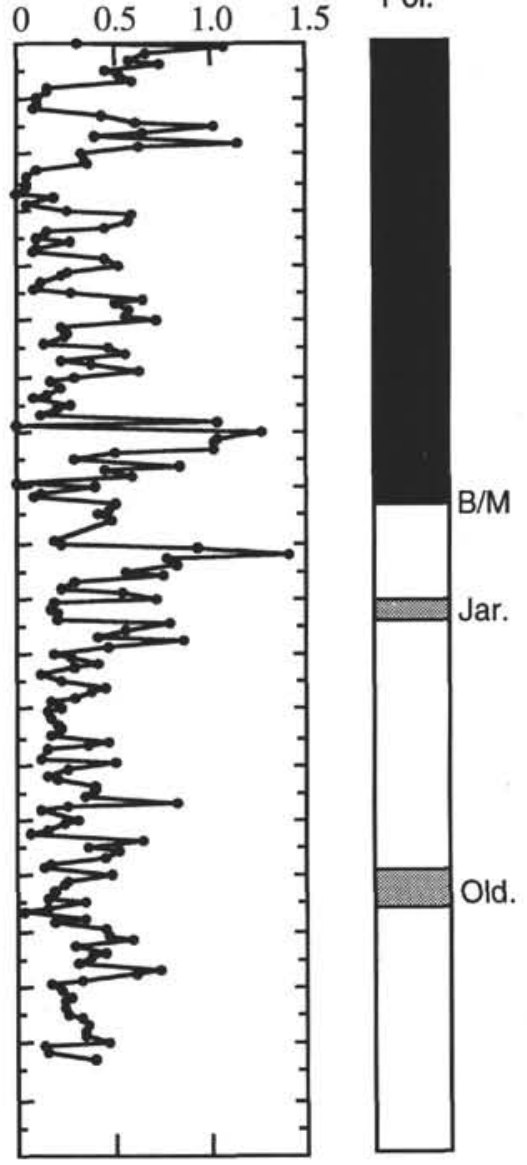

Figure 2. Downhole plots of low-field magnetic susceptibility, bulk sediment composition, the ratio of the weight percentage of lithogenic silt + clay to the weight percentage of lithogenic sand, and the ratio of the weight percentage of calcium carbonate to the weight percentage of lithogenic sand. Plots are shown vs. depth in meters below seafloor (mbsf) in Hole 880A. The cumulative curves of sediment composition represent, from left to right, (1) weight percentage of calcium carbonate $+(2)$ weight percentage of lithogenic sand-sized particles $+(3)$ weight percentage of lithogenic silt/clay-sized particles $=100 \%$. The interpreted magnetic polarity reversal stratigraphy is also shown.

plus wt $\%$-lithogenic sand, plus wt $\%$-lithogenic silt + clay, respectively); (3) the ratio of the weight percentage of lithogenic silt + clay (wt\%-eolian) to the weight percentage of lithogenic sand in order to emphasize changes in the fine-grained lithogenic fraction; and (4) the ratio of the weight percentage of calcium carbonate to the weight percentage of lithogenic sand in order to emphasize changes in the carbonate content of these samples. These comparisons provide the basis for future stratigraphic studies at this site.

Section 144-880A-1H-1 is primarily composed of a foraminifer sand with nannofossils and clay. Figure 3 shows the fluctuations in magnetic susceptibility and sediment composition for this section as related to changes in sediment color. The weight percentage of calcium carbonate in Section 144-880A-1H-1 increases in the interval from 0 to $0.75 \mathrm{mbsf}$ and below $1.3 \mathrm{mbsf}$, but decreases from 0.80 to 1.25 mbsf. Within this low-carbonate interval (associated with generally high values of magnetic susceptibility), there is an increase in the percentage of lithogenic particles, including opaque grains and rock fragments. Peaks in magnetic susceptibility occur within two grayish brown (10YR 5/2) colored zones, at $\sim 0.80$ to $0.90 \mathrm{mbsf}$ and at 1.2 mbsf, respectively.

Below an irregular contact at 1.26 to $1.32 \mathrm{mbsf}$, there is an overall increase in carbonate content that continues into the upper portion of Section 144-880A-1H-2 (Fig. 4), which is associated with fluctuations in the relative amounts of foraminifers, opaque sand grains, and clay. The amount of volcaniclastic and opaque sand in the lower portion of Section 144-880A-1H-2 increases to $90 \%$. A broad increase in magnetic susceptibility is observed from 2.1 to $2.6 \mathrm{mbsf}$, with two maxima at 2.3 to 2.5 and at $\sim 2.8 \mathrm{mbsf}$.

Two layers of predominantly glassy, lighter colored volcaniclastic sand are identified at 2.11-2.16 mbsf and at 2.60-2.72 mbsf (Premoli Silva, Haggerty, Rack, et al., 1993). The upper glassy layer is olive gray $(5 Y 5 / 2)$ and forms a sharp contact with a grayish black (N2) layer of opaque sand grains. The lower glassy layer is also marked by fairly sharp upper and lower contacts and lighter colored layers of pale yellow-green (10GY 7/2) and gray (5Y 6/2). The peaks in magnetic susceptibility, at 2.5 and $2.8 \mathrm{mbsf}$, bracket this lower interval of volcanic glass (Fig. 4).

The upper $50 \mathrm{~cm}$ of Section 144-880A-1H-3 (Fig. 5) consists of grayish brown (10YR 5/2) foraminifer sand with opaque grains and rock fragments. The carbonate content decreases from $33 \%$ at 3.1 mbsf to $<7 \%$ at 3.5 mbsf. A layer of pale yellow-green (10GY $7 / 6$ ) volcanic ash at $3.50-3.54$ mbsf contains over $26 \%$ fine-grained particles. A sharp lower contact with a 3-cm-thick layer of dark-colored lithoclast sand composed of $40 \%$ (volcanic) rock fragments, $25 \%$ opaque grains, $15 \%$ nannofossils, and $10 \%$ clay is observed at $\sim 3.54$ mbsf (Premoli Silva, Haggerty, Rack, et al., 1993).

A grayish brown (10YR 5/2) volcaniclastic sand with foraminifers from 3.6 to $\sim 3.9$ mbsf is interrupted by a 3 -cm-thick pale yellow- 
Table 2. Magnetic susceptibility and NRM intensity measurements, and frequency-dependent susceptibility, Hole 880A.

\begin{tabular}{|c|c|c|c|c|c|}
\hline $\begin{array}{l}\text { Core, section } \\
\text { interval }(\mathrm{cm})\end{array}$ & $\begin{array}{l}\text { Depth } \\
\text { (mbsf) }\end{array}$ & $\begin{array}{l}\chi_{\mathrm{II}} \\
\text { (SI) }\end{array}$ & $\begin{array}{l}\chi_{\mathrm{hf}} \\
(\mathrm{SI})\end{array}$ & $\begin{array}{l}\text { Intensity } \\
\text { (SI) }\end{array}$ & $\begin{array}{l}\chi_{\mathrm{fd}} \\
(\%)\end{array}$ \\
\hline \multicolumn{6}{|l|}{$144-880 \mathrm{~A}-$} \\
\hline $1 \mathrm{H}-1,0-2$ & 0.00 & 39.56 & 37.35 & 2.60 & 5.59 \\
\hline IH-1, $10-12$ & 0.10 & 16.70 & 16.25 & 14.77 & 2.69 \\
\hline $1 \mathrm{H}-1,20-22$ & 0.20 & 26.34 & 25.63 & 22.39 & 2.70 \\
\hline $1 \mathrm{H}-1,30-32$ & 0.30 & 29.34 & 28.32 & 22.51 & 3.48 \\
\hline IH-1, $40-42$ & 0.40 & 28.60 & 27.77 & 24.95 & 2.90 \\
\hline $1 \mathrm{H}-1,50-52$ & 0.50 & 20.00 & 19.41 & 17.51 & 2.95 \\
\hline $1 \mathrm{H}-1,59-61$ & 0.59 & 30.48 & 29.38 & 27.90 & 3.61 \\
\hline $1 \mathrm{H}-1,70-72$ & 0.70 & 30.07 & 29.18 & 23.09 & 2.96 \\
\hline $\mathrm{IH}-1,81-83$ & 0.81 & 48.24 & 46.73 & 40.09 & 3.13 \\
\hline $1 \mathrm{H}-1,90-92$ & 0.90 & 46.43 & 44.87 & 30.37 & 3.36 \\
\hline $1 \mathrm{H}-1,100-102$ & 1.00 & 32.67 & 31.65 & 22.02 & 3.12 \\
\hline $1 \mathrm{H}-1,110-112$ & 1.10 & 33.16 & 31.33 & 31.32 & 5.52 \\
\hline $1 \mathrm{H}-1,120-122$ & 1.20 & 48.81 & 47.53 & 46.05 & 2.62 \\
\hline $1 \mathrm{H}-1,130-132$ & 1.30 & 30.45 & 29.65 & 29.37 & 2.63 \\
\hline $1 \mathrm{H}-1,140-142$ & 1.40 & 40.42 & 38.32 & 34.76 & 5.20 \\
\hline $1 \mathrm{H}-2,1-3$ & 1.51 & 23.91 & 23.27 & 25.02 & 2.68 \\
\hline $1 \mathrm{H}-2,10-12$ & 1.60 & 22.63 & 21.87 & 17.93 & 3.36 \\
\hline $1 \mathrm{H}-2,20-22$ & 1.70 & 21.47 & 20.79 & 17.75 & 3.17 \\
\hline IH $-2,30-32$ & 1.80 & 23.91 & 24.03 & 21.05 & - \\
\hline IH $-2,38-40$ & 1.88 & 29.42 & 27.66 & 22.17 & 5.98 \\
\hline IH-2, $50-52$ & 2.00 & 27.44 & 26.45 & 21.82 & 3.61 \\
\hline IH-2, 61-63 & 2.11 & 19.37 & 18.80 & 15.09 & 2.94 \\
\hline $1 \mathrm{H}-2,68-70$ & 2.18 & 29.58 & 28.63 & 26.01 & 3.21 \\
\hline $1 \mathrm{H}-2,80-82$ & 2.30 & 45.58 & 44.30 & 41.26 & 2.81 \\
\hline $1 \mathrm{H}-2,90-92$ & 2.40 & 37.56 & 36.25 & 34.85 & 3.49 \\
\hline $1 \mathrm{H}-2,100-102$ & 2.50 & 61.87 & 60.37 & 73.90 & 2.42 \\
\hline $1 \mathrm{H}-2,110-112$ & 2.60 & 21.19 & 20.70 & 20.58 & 2.31 \\
\hline $1 \mathrm{H}-2,119-121$ & 2.69 & 11.75 & 11.30 & 5.86 & 3.83 \\
\hline $1 \mathrm{H}-2,130-132$ & 2.80 & 45.35 & 44.00 & 37.12 & 2.98 \\
\hline IH- $2,140-142$ & 2.90 & 28.65 & 28.11 & 20.89 & 1.88 \\
\hline IH $-3,1-3$ & 3.01 & 32.01 & 31.15 & 19.09 & 2.69 \\
\hline $1 \mathrm{H}-3,10-12$ & 3.10 & 23.11 & 22.47 & 17.51 & 2.77 \\
\hline $1 \mathrm{H}-3,20-22$ & 3.20 & 29.16 & 29.24 & 25.69 & - \\
\hline $1 \mathrm{H}-3,30-32$ & 3.30 & 36.38 & 35.59 & 29.26 & 2.17 \\
\hline $1 \mathrm{H}-3,40-42$ & 3.40 & 37.68 & 36.81 & 32.65 & 2.31 \\
\hline $1 \mathrm{H}-3,51-53$ & 3.51 & 29.46 & 28.25 & 14.30 & 4.11 \\
\hline $1 \mathrm{H}-3,59-61$ & 3.59 & 43.08 & 40.72 & 37.38 & 5.48 \\
\hline IH $-3,71-73$ & 3.71 & 60.32 & 59.16 & 51.97 & 1.92 \\
\hline IH-3, 78-80 & 3.78 & 47.56 & 44.98 & 46.94 & 5.42 \\
\hline $1 \mathrm{H}-3,90-92$ & 3.90 & 36.68 & 34.61 & 30.30 & 5.64 \\
\hline $1 \mathrm{H}-3,100-102$ & 4.00 & 29.06 & 29.13 & 22.92 & - \\
\hline $1 \mathrm{H}-3,110-112$ & 4.10 & 36.67 & 35.53 & 30.82 & 3.11 \\
\hline $1 \mathrm{H}-3,118-120$ & 4.18 & 34.51 & 33.69 & 26.80 & 2.38 \\
\hline $1 \mathrm{H}-3,130-132$ & 4.30 & 38.73 & 36.65 & 32.87 & 5.37 \\
\hline $1 \mathrm{H}-3,140-142$ & 4.40 & 37.76 & 36.77 & 29.34 & 2.62 \\
\hline IH $-4,0-2$ & 4.50 & 23.31 & 22.87 & 22.68 & 1.89 \\
\hline $1 \mathrm{H}-4,10-12$ & 4.60 & 34.78 & 32.96 & 28.34 & 5.23 \\
\hline IH $-4,20-22$ & 4.70 & 33.07 & 31.57 & 26.72 & 4.54 \\
\hline $1 \mathrm{H}-4,30-32$ & 4.80 & 36.71 & 36.24 & 30.49 & 1.28 \\
\hline $1 \mathrm{H}-4,40-42$ & 4.90 & 32.50 & 30.84 & 23.88 & 5.11 \\
\hline IH $-4,48-50$ & 4.98 & 28.87 & 27.37 & 21.23 & 5.20 \\
\hline $1 \mathrm{H}-4,60-62$ & 5.10 & 39.22 & 37.02 & 29.26 & 5.61 \\
\hline $1 \mathrm{H}-4,70-72$ & 5.20 & 35.60 & 33.88 & 29.21 & 4.83 \\
\hline 1H $-4,80-82$ & 5.30 & 28.80 & 28.22 & 23.89 & 2.01 \\
\hline $1 \mathrm{H}-4,90-92$ & 5.40 & 3.51 & 3.34 & 1.97 & 4.84 \\
\hline $1 \mathrm{H}-4,98-100$ & 5.48 & 30.07 & 29.47 & 38.33 & 2.00 \\
\hline $1 \mathrm{H}-4,110-112$ & 5.60 & 12.96 & 12.78 & 9.14 & 1.39 \\
\hline $1 \mathrm{H}-4,120-122$ & 5.70 & 12.68 & 12.52 & 8.82 & 1.26 \\
\hline $1 \mathrm{H}-4,130-132$ & 5.80 & 20.42 & 20.65 & 16.44 & - \\
\hline IH $-4,138-140$ & 5.88 & 29.04 & 27.75 & 24.87 & 4.44 \\
\hline IH $-5,1-3$ & 6.01 & 28.76 & 27.25 & 19.64 & 5.25 \\
\hline $1 \mathrm{H}-5,10-12$ & 6.10 & 40.32 & 38.37 & 30.89 & 4.84 \\
\hline $1 \mathrm{H}-5,19-21$ & 6.19 & 28.93 & 29.49 & 22.76 & - \\
\hline $1 \mathrm{H}-5,30-32$ & 6.30 & 24.04 & 23.69 & 15.58 & 1.46 \\
\hline IH $-5,39-41$ & 6.39 & 10.58 & 10.48 & 7.60 & 0.95 \\
\hline $1 \mathrm{H}-5,50-52$ & 6.50 & 41.78 & 41.09 & 35.30 & 1.65 \\
\hline IH $-5,59-61$ & 6.59 & 34.03 & 34.82 & 26.88 & - \\
\hline IH $-5,70-72$ & 6.70 & 43.84 & 43.16 & 35.13 & 1.55 \\
\hline 1Н $-5,80-82$ & 6.80 & 31.01 & 29.76 & 22.48 & 4.03 \\
\hline IH-5, 90-92 & 6.90 & 6.51 & 6.53 & 2.21 & - \\
\hline IH-5, 98-100 & 6.98 & 18.17 & 18.02 & 12.80 & 0.83 \\
\hline $1 \mathrm{H}-5,110-112$ & 7.10 & 24.04 & 23.80 & 18.91 & 1.00 \\
\hline $1 \mathrm{H}-5,120-122$ & 7.20 & 19.45 & 19.15 & 13.16 & 1.54 \\
\hline $1 \mathrm{H}-5,130-132$ & 7.30 & 17.10 & 16.86 & 12.18 & 1.40 \\
\hline IH $-5,140-142$ & 7.40 & 22.85 & 23.43 & 18.78 & - \\
\hline 1H-6, 0-2 & 7.50 & 35.67 & 36.35 & 33.97 & - \\
\hline $1 \mathrm{H}-6,10-12$ & 7.60 & 18.86 & 19.20 & 17.12 & - \\
\hline $1 \mathrm{H}-6,20-22$ & 7.70 & 22.11 & 21.42 & 22.52 & 3.12 \\
\hline IH-6, 30-32 & 7.80 & 21.66 & 21.46 & 22.27 & 0.92 \\
\hline $1 \mathrm{H}-6,40-42$ & 7.90 & 5.22 & 5.09 & 4.41 & 2.49 \\
\hline IH $-6,48-50$ & 7.98 & 33.80 & 33.16 & 27.31 & 1.89 \\
\hline 1H-6, 60-62 & 8.10 & 20.55 & 20.48 & 17.61 & 0.34 \\
\hline $1 \mathrm{H}-6,71-73$ & 8.20 & 43.23 & 42.77 & 52.87 & 1.06 \\
\hline IH-6, $80-82$ & 8.30 & 32.12 & 30.71 & 34.11 & 4.39 \\
\hline $1 \mathrm{H}-6,90-92$ & 8.40 & 22.05 & 21.75 & 25.83 & 1.36 \\
\hline $1 \mathrm{H}-6,100-102$ & 8.50 & 16.94 & 16.67 & 12.98 & 1.59 \\
\hline $1 \mathrm{H}-6,110-112$ & 8.60 & 24.60 & 24.10 & 5.95 & 2.03 \\
\hline
\end{tabular}

\begin{tabular}{|c|c|c|c|c|c|}
\hline $\begin{array}{l}\text { Core, section } \\
\text { interval }(\mathrm{cm})\end{array}$ & $\begin{array}{l}\text { Depth } \\
\text { (mbsf) }\end{array}$ & $\begin{array}{l}\chi_{\mathrm{If}} \\
(\mathrm{SI})\end{array}$ & $\begin{array}{l}\chi_{\mathrm{hf}} \\
\text { (SI) }\end{array}$ & $\begin{array}{l}\text { Intensity } \\
\text { (SI) }\end{array}$ & $\begin{array}{l}\chi_{\mathrm{fd}} \\
(\%)\end{array}$ \\
\hline $2 \mathrm{H}-1,5-7$ & 8.95 & 36.17 & 35.68 & 36.39 & 1.35 \\
\hline $2 \mathrm{H}-1,11-13$ & 9.01 & 31.69 & 31.41 & 33.71 & 0.88 \\
\hline $2 \mathrm{H}-1,20-22$ & 9.10 & 16.51 & 16.70 & 15.66 & - \\
\hline $2 \mathrm{H}-1,29-31$ & 9.19 & 10.07 & 9.90 & 9.84 & 1.69 \\
\hline $2 \mathrm{H}-1,40-42$ & 9.30 & 8.45 & 8.28 & 9.73 & 2.01 \\
\hline $2 \mathrm{H}-1,50-52$ & 9.40 & 14.77 & 14.52 & 20.03 & 1.69 \\
\hline $2 \mathrm{H}-1,59-61$ & 9.49 & 13.51 & 13.32 & 14.82 & 1.41 \\
\hline $2 \mathrm{H}-1,71-73$ & 9.61 & 16.34 & 16.06 & 21.01 & 1.71 \\
\hline $2 \mathrm{H}-1,80-82$ & 9.70 & 19.62 & 19.28 & 21.60 & 1.73 \\
\hline $2 \mathrm{H}-1,90-92$ & 9.80 & 24.46 & 24.09 & 28.41 & 1.51 \\
\hline $2 \mathrm{H}-1,100-102$ & 9.90 & 19.10 & 18.87 & 22.58 & 1.20 \\
\hline $2 \mathrm{H}-1,110-112$ & 10.00 & 16.71 & 16.46 & 16.75 & 1.50 \\
\hline $2 \mathrm{H}-\mathrm{I}, 120-122$ & 10.10 & 43.83 & 44.33 & 43.54 & - \\
\hline $2 \mathrm{H}-1,130-132$ & 10.20 & 49.93 & 49.30 & 46.06 & 1.26 \\
\hline $2 \mathrm{H}-2,0-2$ & 10.27 & 35.59 & 34.72 & 30.76 & 2.44 \\
\hline $2 \mathrm{H}-2,10-12$ & 10.37 & 41.90 & 41.12 & 33.42 & 1.86 \\
\hline $2 \mathrm{H}-2,20-22$ & 10.47 & 25.94 & 25.47 & 20.79 & 1.81 \\
\hline $2 \mathrm{H}-2,27-29$ & 10.54 & 29.67 & 29.19 & 25.57 & 1.62 \\
\hline $2 \mathrm{H}-2,40-42$ & 10.67 & 22.31 & 21.91 & 19.79 & 1.79 \\
\hline $2 \mathrm{H}-2,50-52$ & 10.77 & 22.53 & 22.18 & 19.96 & 1.55 \\
\hline $2 \mathrm{H}-2,57-59$ & 10.84 & 25.67 & 25.17 & 22.42 & 1.95 \\
\hline $2 \mathrm{H}-2,70-72$ & 10.97 & 33.57 & 33.90 & 29.52 & - \\
\hline $2 \mathrm{H}-2,77-79$ & 11.04 & 23.32 & 22.85 & 23.68 & 2.02 \\
\hline $2 \mathrm{H}-2,90-92$ & 11.17 & 29.85 & 29.47 & 31.25 & 1.27 \\
\hline $2 \mathrm{H}-2,100-102$ & 11.27 & 32.76 & 32.62 & 31.51 & 0.43 \\
\hline $2 \mathrm{H}-2,110-112$ & 11.37 & 30.89 & 30.67 & 28.48 & 0.71 \\
\hline $2 \mathrm{H}-2,120-122$ & 11.47 & 27.71 & 27.52 & 27.02 & 0.69 \\
\hline $2 \mathrm{H}-2,132-134$ & 11.59 & 19.33 & 19.08 & 16.43 & 1.29 \\
\hline $2 \mathrm{H}-2,140-142$ & 11.67 & 26.71 & 26.44 & 23.59 & 1.01 \\
\hline $2 \mathrm{H}-3, \mathrm{l}-3$ & 11.78 & 23.77 & 23.55 & 27.90 & 0.93 \\
\hline $2 \mathrm{H}-3,10-12$ & 11.87 & 31.74 & 32.30 & 35.17 & - \\
\hline $2 \mathrm{H}-3,20-22$ & 11.97 & 25.51 & 25.51 & 27.73 & 0.00 \\
\hline $2 \mathrm{H}-3,27-29$ & 12.04 & 30.24 & 29.88 & 31.12 & 1.19 \\
\hline $2 \mathrm{H}-3,40-42$ & 12.17 & 15.67 & 15.56 & 13.33 & 0.70 \\
\hline $2 \mathrm{H}-3,50-52$ & 12.27 & 9.88 & 9.88 & 8.95 & 0.00 \\
\hline $2 \mathrm{H}-3,58-60$ & 12.35 & 23.96 & 23.18 & 25.44 & 3.26 \\
\hline $2 \mathrm{H}-3,70-72$ & 12.47 & 8.56 & 8.46 & 11.70 & 1.17 \\
\hline $2 \mathrm{H}-3,80-82$ & 12.57 & 16.34 & 16.17 & 21.26 & 1.04 \\
\hline $2 \mathrm{H}-3,90-92$ & 12.67 & 25.56 & 25.54 & 23.32 & 0.08 \\
\hline $2 \mathrm{H}-3,97-99$ & 12.74 & 18.81 & 18.75 & 14.36 & 0.32 \\
\hline $2 \mathrm{H}-3,110-112$ & 12.87 & 10.44 & 10.43 & 7.50 & 0.10 \\
\hline $2 \mathrm{H}-3,120-122$ & 12.97 & 31.40 & 31.30 & 26.40 & 0.32 \\
\hline $2 \mathrm{H}-3,130-132$ & 13.07 & 28.43 & 29.13 & 30.91 & - \\
\hline $2 \mathrm{H}-3,140-142$ & 13.17 & 35.36 & 35.24 & 33.56 & 0.34 \\
\hline $2 \mathrm{H}-4,0-2$ & 13.27 & 23.46 & 23.28 & 26.34 & 0.77 \\
\hline $2 \mathrm{H}-4,10-12$ & 13.37 & 30.05 & 29.77 & 34.14 & 0.93 \\
\hline $2 \mathrm{H}-4,20-22$ & 13.47 & 26.80 & 26.47 & 25.00 & 1.23 \\
\hline $2 \mathrm{H}-4,30-32$ & 13.57 & 19.66 & 19.57 & 18.35 & 0.46 \\
\hline $2 \mathrm{H}-4,40-42$ & 13.67 & 14.26 & 14.21 & 12.98 & 0.35 \\
\hline $2 \mathrm{H}-4,50-52$ & 13.77 & 25.26 & 24.37 & 21.45 & 3.52 \\
\hline $2 \mathrm{H}-4,57-59$ & 13.84 & 25.97 & 25.87 & 23.85 & 0.39 \\
\hline $2 \mathrm{H}-4,72-74$ & 13.99 & 26.76 & 27.54 & 27.80 & - \\
\hline $2 \mathrm{H}-4,80-82$ & 14.07 & 41.58 & 40.58 & 39.52 & 2.41 \\
\hline $2 \mathrm{H}-4,90-92$ & 14.17 & 26.78 & 26.72 & 24.58 & 0.22 \\
\hline $2 \mathrm{H}-4,100-102$ & 14.27 & 12.03 & 12.03 & 8.70 & 0.00 \\
\hline $2 \mathrm{H}-4,110-112$ & 14.37 & 26.27 & 26.12 & 27.68 & 0.57 \\
\hline $2 \mathrm{H}-4,120-122$ & 14.47 & 28.17 & 27.91 & 26.99 & 0.92 \\
\hline $2 \mathrm{H}-4,130-132$ & 14.57 & 32.79 & 31.71 & 28.01 & 3.29 \\
\hline $2 \mathrm{H}-4,140-142$ & 14.67 & 32.65 & 32.47 & 32.51 & 0.55 \\
\hline $2 \mathrm{H}-5,0-2$ & 14.77 & 37.02 & 35.59 & 36.44 & 3.86 \\
\hline $2 \mathrm{H}-5,10-12$ & 14.87 & 31.88 & 31.62 & 38.17 & 0.82 \\
\hline $2 \mathrm{H}-5,20-22$ & 14.97 & 26.09 & 25.70 & 26.65 & 1.49 \\
\hline $2 \mathrm{H}-5,30-32$ & 15.07 & 35.39 & 34.05 & 40.53 & 3.79 \\
\hline $2 \mathrm{H}-5,40-42$ & 15.17 & 44.64 & 45.76 & 47.93 & - \\
\hline $2 \mathrm{H}-5,50-52$ & 15.27 & 33.96 & 33.53 & 32.56 & 1.27 \\
\hline $2 \mathrm{H}-5,62-64$ & 15.39 & 49.34 & 48.60 & 46.36 & 1.50 \\
\hline $2 \mathrm{H}-5,72-74$ & 15.49 & 47.25 & 46.45 & 40.63 & 1.69 \\
\hline $2 \mathrm{H}-5,80-82$ & 15.57 & 28.78 & 29.24 & 25.67 & - \\
\hline $2 \mathrm{H}-5,88-90$ & 15.65 & 13.77 & 13.53 & 9.10 & 1.74 \\
\hline $2 \mathrm{H}-5,100-102$ & 15.77 & 38.01 & 37.73 & 33.36 & 0.74 \\
\hline $2 \mathrm{H}-5,109-111$ & 15.86 & 36.49 & 35.81 & 31.88 & 1.86 \\
\hline $2 \mathrm{H}-5,120-122$ & 15.97 & 51.31 & 51.03 & 57.65 & 0.55 \\
\hline $2 \mathrm{H}-5,129-131$ & 16.06 & 27.31 & 26.36 & 29.47 & 3.48 \\
\hline $2 \mathrm{H}-5,136-138$ & 16.13 & 27.17 & 26.03 & 26.99 & 4.20 \\
\hline $2 \mathrm{H}-6,0-2$ & 16.27 & 28.32 & 27.05 & 24.40 & 4.48 \\
\hline $2 \mathrm{H}-6,10-12$ & 16.37 & 37.83 & 37.66 & 30.34 & 0.45 \\
\hline $2 \mathrm{H}-6,20-22$ & 16.47 & 9.32 & 9.02 & 6.56 & 3.22 \\
\hline $2 \mathrm{H}-6,30-32$ & 16.57 & 29.72 & 29.43 & 28.78 & 0.98 \\
\hline $2 \mathrm{H}-6,40-42$ & 16.67 & 21.82 & 21.69 & 21.60 & 0.60 \\
\hline $2 \mathrm{H}-6,50-52$ & 16.77 & 29.30 & 23.05 & 17.87 & 21.33 \\
\hline $2 \mathrm{H}-6,60-62$ & 16.87 & 24.94 & 25.81 & 21.59 & - \\
\hline $2 \mathrm{H}-6,69-71$ & 16.96 & 27.65 & 27.65 & 23.37 & 0.00 \\
\hline $2 \mathrm{H}-6,81-83$ & 17.08 & 20.29 & 20.09 & 15.77 & 0.99 \\
\hline $2 \mathrm{H}-6,90-92$ & 17.17 & 24.60 & 23.91 & 21.81 & 2.80 \\
\hline $2 \mathrm{H}-6,97-99$ & 17.24 & 11.49 & 11.45 & 10.11 & 0.35 \\
\hline $2 \mathrm{H}-6,110-112$ & 17.37 & 5.99 & 5.98 & 4.78 & 0.17 \\
\hline $2 \mathrm{H}-6,120-122$ & 17.47 & 15.86 & 15.80 & 14.02 & 0.38 \\
\hline $2 \mathrm{H}-6,130-132$ & 17.57 & 18.33 & 18.20 & 16.79 & 0.71 \\
\hline
\end{tabular}


Table 2 (continued).

\begin{tabular}{lccccc}
\hline $\begin{array}{c}\text { Core, section } \\
\text { interval }(\mathrm{cm})\end{array}$ & $\begin{array}{c}\text { Depth } \\
(\mathrm{mbs})\end{array}$ & $\begin{array}{c}\chi_{\mathrm{lf}} \\
(\mathrm{SI})\end{array}$ & $\begin{array}{c}\chi_{\mathrm{hf}} \\
(\mathrm{SI})\end{array}$ & $\begin{array}{c}\text { Intensity } \\
(\mathrm{SI})\end{array}$ & $\begin{array}{c}\chi_{\mathrm{fd}} \\
(\%)\end{array}$ \\
\hline $2 \mathrm{H}-6,139-141$ & 17.66 & 25.96 & 25.03 & 22.28 & 3.58 \\
$2 \mathrm{H}-7,0-2$ & 17.77 & 15.22 & 15.19 & 15.89 & 0.20 \\
$2 \mathrm{H}-7,10-12$ & 17.87 & 21.96 & 21.85 & 24.63 & 0.50 \\
$2 \mathrm{H}-7,20-22$ & 17.97 & 18.70 & 18.69 & 20.12 & 0.05 \\
$2 \mathrm{H}-7,30-32$ & 18.07 & 39.49 & 39.30 & 58.03 & 0.48 \\
$2 \mathrm{H}-7,40-42$ & 18.17 & 37.18 & 36.89 & 85.79 & 0.78 \\
$2 \mathrm{H}-7,52-54$ & 18.29 & 26.19 & 26.04 & 12.24 & 0.57 \\
\end{tabular}

Notes: $\chi_{\mathrm{If}}=$ low-field magnetic susceptibility (in nondimensional SI units); $\chi_{\mathrm{hf}}=$ highfield magnetic susceptibility (in SI units); Intensity $=$ NRM intensity (SI units); $c_{\mathrm{fd}}$ $=$ frequency dependent susceptibility $(\%)$.

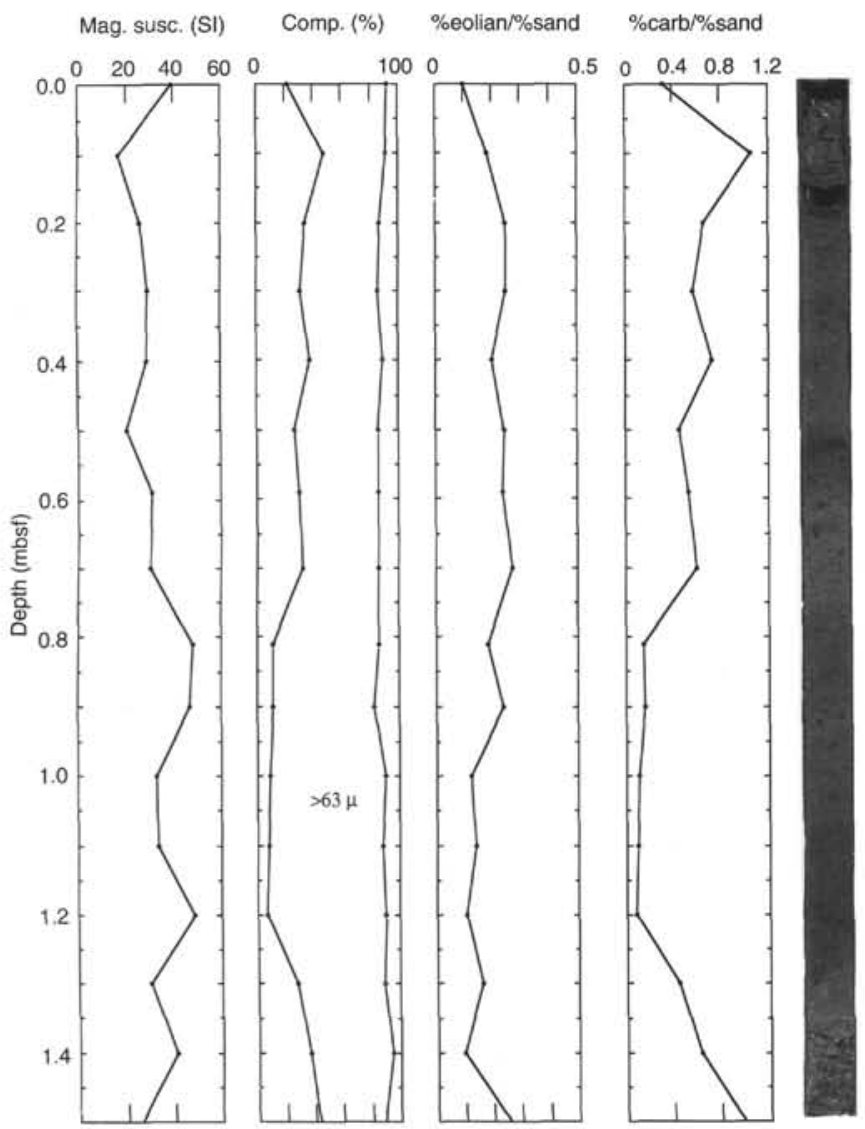

Figure 3. Comparisons between downhole sediment properties and the core photograph for Section 144-880A-1H-1 (0-1.5 mbsf). Plots are shown vs. depth (mbsf) in Hole 880A for low-field magnetic susceptibility (in dimensionless SI units), bulk sediment composition (shown as cumulative weight percentage [wt\%] curves of, from left to right: [1] calcium carbonate $+[2]$ lithogenic sand $+[3]$ lithogenic silt + clay $=100 \%$ ), the ratio of wt $\%$-eolian (i.e., wt\%-lithogenic silt + clay) to wt\%-lithogenic sand, and the ratio of wt $\%$-carbonate to wt\%-lithogenic sand.

green (10GY 7/2) volcaniclastic sand layer at $\sim 3.7$ mbsf. A large peak in magnetic susceptibility is observed just below this layer, where the percentage of lithogenic and volcanic material increases to $90 \%$. A relatively sharp change is noted at $3.9 \mathrm{mbsf}$, where the sediment changes to a lighter colored, olive gray ( 5 Y $5 / 2$ ) nannofossil-foraminifer ooze that continues downhole to $4.15 \mathrm{mbsf}$. The carbonate content of this ooze decreases from $40 \%$ at $3.9 \mathrm{mbsf}$ to $<10 \%$ at $4.3 \mathrm{mbsf}$. Volcanic glass, lithoclasts, and opaque grains all increase toward the base of Section 144-880A-1H-3 (Premoli Silva, Haggerty, Rack, et al., 1993).
Table 3. Magnetic polarity transition observed in Hole 880A.

\begin{tabular}{llc}
\hline \multicolumn{1}{c}{ Chron } & $\begin{array}{c}\text { Core, section, } \\
\text { interval }(\mathrm{cm})\end{array}$ & $\begin{array}{c}\text { Depth } \\
\text { (mbsf) }\end{array}$ \\
\hline $\begin{array}{l}\text { Brunhes } \\
\text { Matuyama }\end{array}$ & $\begin{array}{l}1 \mathrm{H}-6,60 \\
1 \mathrm{H}-6,100\end{array}$ & 8.45 \\
$\begin{array}{l}\text { Matuyama } \\
\text { Jaramillo (?) }\end{array}$ & $\begin{array}{l}2 \mathrm{H}-1,120 \\
2 \mathrm{H}-1,130\end{array}$ & 10.15 \\
$\begin{array}{l}\text { Jaramillo (?) } \\
\text { Matuyama }\end{array}$ & $\begin{array}{l}2 \mathrm{H}-2,20 \\
2 \mathrm{H}-2,27\end{array}$ & 10.50 \\
$\begin{array}{l}\text { Matuyama } \\
\text { Olduvai }\end{array}$ & $2 \mathrm{H}-5,20$ & 15.02 \\
$\begin{array}{l}\text { Olduvai (?) } \\
\text { Matuyama }\end{array}$ & $2 \mathrm{H}-5,30$ & 15.71 \\
\hline & $2 \mathrm{H}-5,88$ & \\
\hline
\end{tabular}

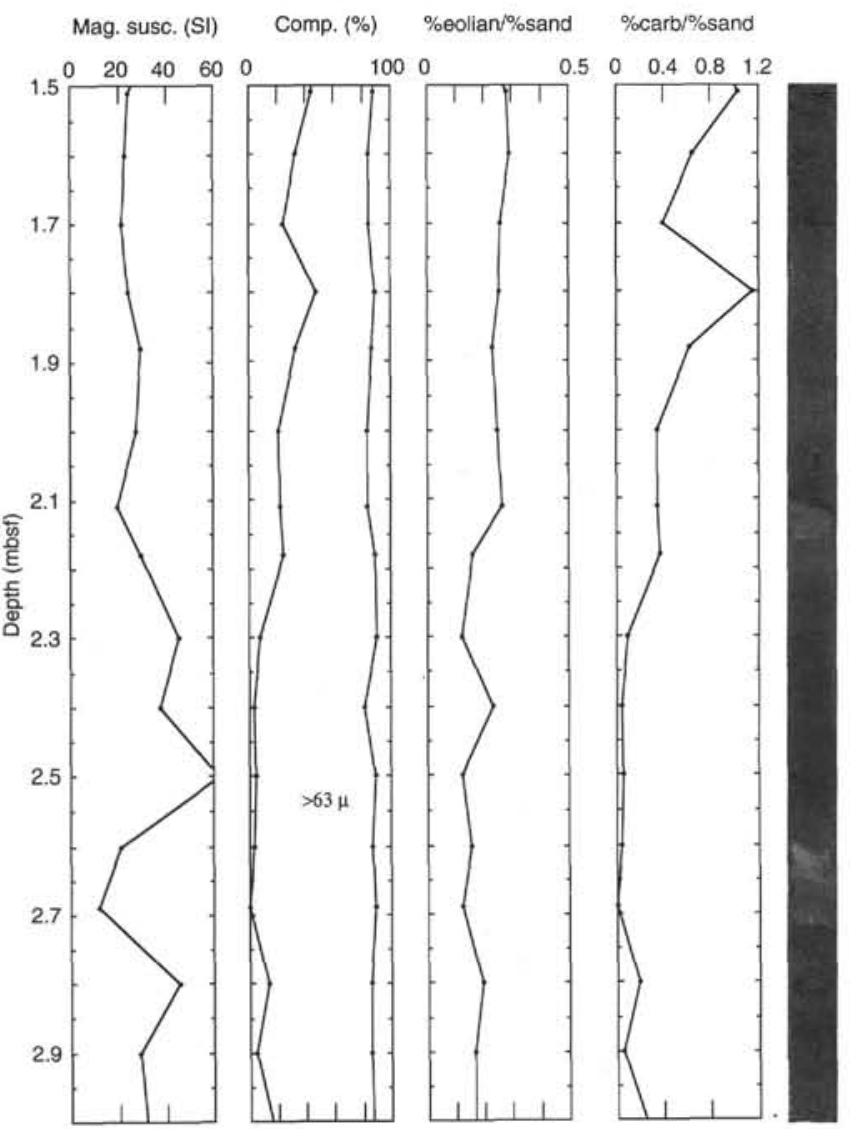

Figure 4. Comparisons between downhole sediment properties and the core photograph for Section 144-880A-1H-2 (1.5-3.0 mbsf).

In Section 144-880A-1H-4 (Fig. 6), an interval of dark grayish brown $(2.5 \mathrm{Y} 4 / 2)$ nannofossil foraminifer ooze from 4.5 to $5.1 \mathrm{mbsf}$, overlies a lighter colored, patchy interval of dark grayish brown to olive gray ( 5 Y 5/2) foraminifer nannofossil ooze from 5.1 to $5.9 \mathrm{mbsf}$. The color transition from $\sim 5.0$ to 5.45 mbsf (dark above to light below) seems to correspond to a change in the relative grain size and abundance of the lithogenic fraction. Alayer of coarse volcanic ash(?) may be indicated at $\sim 5.4 \mathrm{mbsf}$ by the low magnetic susceptibility value and the increased percentage of coarse-grained lithogenic particles at this level.

In Section 144-880A-1H-5 (Fig. 7), a prominent light brownish gray (10YR 6/2) ash layer from 6.4 to $6.45 \mathrm{mbsf}$ is located between two dark-colored volcaniclastic sands. Underlying the lower sand, an olive gray $(5 \mathrm{Y} 5 / 2)$ nannofossil foraminifer ooze layer from 6.79 to 6.85 mbsf overlies another volcanic ash layer. An interval of olive gray (5Y 5/2) nannofossil foraminifer sand from 6.95 to $7.44 \mathrm{mbsf}$ forms a sharp lower contact with this volcanic ash. Darker patches in 


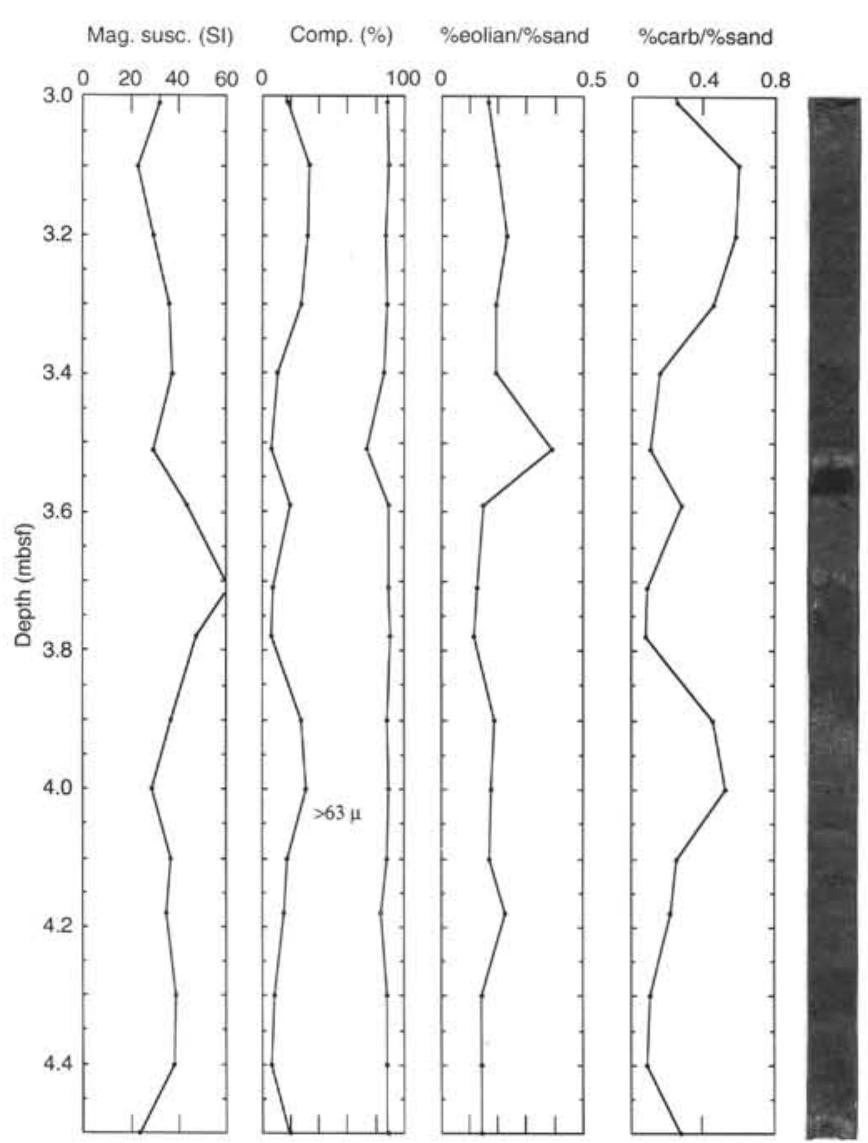

Figure 5. Comparisons between downhole sediment properties and the core photograph for Section 144-880A-1H-3 (3.0-4.5 mbsf).

this lower interval contain sand-sized lithoclasts and opaque grains. Coarser grains and rounded $(0.5-1 \mathrm{~cm})$, light gray pebbles with sparse dark phenocrysts are observed near the base of this ooze (Premoli Silva, Haggerty, Rack, et al., 1993).

The upper $36 \mathrm{~cm}$ of Section 144-880A-1H-6 (Fig. 8) consists of a dark grayish brown, fine-grained volcaniclastic sand with foraminifers, which overlies a pinkish gray (5YR 6/2) soft ash. The ash layer is represented by a sharp peak in the percentage of fine-grained lithogenic ("eolian") particles, a low in magnetic susceptibility, and the absence of any calcium carbonate. A $20 \%$ increase in carbonate and an increase in susceptibility are noted just below the base of this ash layer, in the sample at 7.98 mbsf. A peak in susceptibility at 8.2 mbsf is associated with an increase in the percentage of coarsegrained lithogenic material. Strong color changes are observed in the volcaniclastic sand interval from 7.95 mbsf to the base of Core 144$880 \mathrm{~A}-1 \mathrm{H}$. The lighter colored sediment, below $8.3 \mathrm{mbsf}$ to the base of Section 144-880A-1H-6, contains about $30 \%$ calcium carbonate. No samples for this study were taken from the core catcher.

Section 144-880A-2H-1 (Fig. 9) primarily consists of olive gray (5Y $3 / 2$ ) and light olive gray (5Y 5/2) volcaniclastic foraminifer sand, containing variable amounts of calcium carbonate $(10 \%-50 \%)$ and opaque minerals. Large increases in the percentage of coarse-grained lithogenic material are noted above $9.1 \mathrm{mbsf}$ and below $9.6 \mathrm{mbsf}$, whereas the percentage of fine-grained lithogenic material increases to almost $30 \%$ from 8.95 to $9.8 \mathrm{mbsf}$. Increased concentrations of volcanic lapilli are noted at 9.5 and 9.85 mbsf (Premoli Silva, Haggerty, Rack, et al., 1993). A 20\% increase in calcium carbonate is associated with a pale olive (10Y 6/2) volcanic ash from $~ 9.88$ to $10.07 \mathrm{mbsf}$. A peak in magnetic susceptibility occurs at the base of the ash layer.

The volcaniclastic sand described from Section 144-880A-2H-1 continues through Section 144-880A-2H-2 (Fig. 10) and into Section

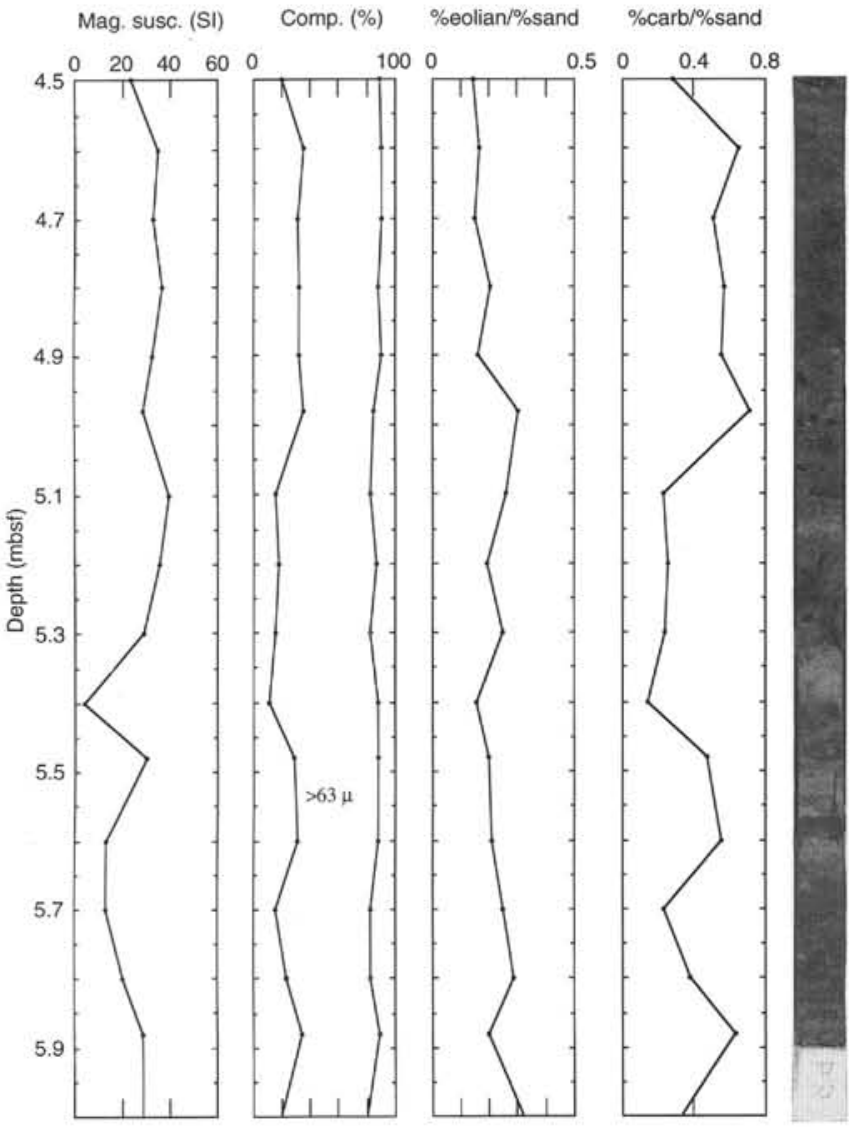

Figure 6. Comparisons between downhole sediment properties and the core photograph for Section 144-880A-1H-4 (4.5-6.0 mbsf).

144-880A-2H-3 (Fig. 11), although notable fluctuations occur in carbonate content and more nannofossils may be present in certain zones (see Erba, this volume). There is another pale olive volcanic ash bed with foraminifers at $\sim 11.7 \mathrm{mbsf}$, and two intervals of volcanic lapilli are described at 11.3 and 11.5 mbsf (Premoli Silva, Haggerty, Rack, et al., 1993). These intervals of volcanic lapilli are similarly positioned relative to the ash bed below, as was observed for the lapilli layers and ash in Section 144-880A-1H-1.

In Section 144-880A-2H-3 (Fig. 11), there are several lightcolored intervals that correspond to increases in the percentage of calcium carbonate, although shifts in the relative percentage of fineto coarse-grained lithogenic material and low values of susceptibility may also indicate appreciable volcanic ash in some layers, such as the lighter intervals near 12.5 and 12.9 mbsf.

Section 144-880A-2H-4 (Fig. 12) is primarily composed of darkcolored, volcaniclastic sand with foraminifers. There are a number of lighter colored layers, including an ash bed at 14.40 to $14.45 \mathrm{mbsf}$ with a sharp lower contact, which is indicated by an increase in the ratio of fine- to coarse-grained lithogenic material. The lower portion of Section 144-880A-2H-4, from 14.35 to 14.7 mbsf, contains $~ 30 \%-$ $35 \%$ calcium carbonate and an increased number of foraminifers (Premoli Silva, Haggerty, Rack, et al., 1993).

The major color change in Section 144-880A-2H-5 (Fig. 13) was observed as a light-colored layer (probably an ash layer) that occurs from 15.65 to $15.7 \mathrm{mbsf}$. This layer is distinguished by low magnetic susceptibility and a large increase in the percentage of fine-grained lithogenic material. Higher values of magnetic susceptibility are observed both above and below the level of the probable ash layer.

Increased amounts of calcium carbonate were observed in Section 144-880A-2H-6 (Fig. 14) between 16.6 and 16.85 mbsf. A decrease in susceptibility and an increased percentage of fine-grained litho- 


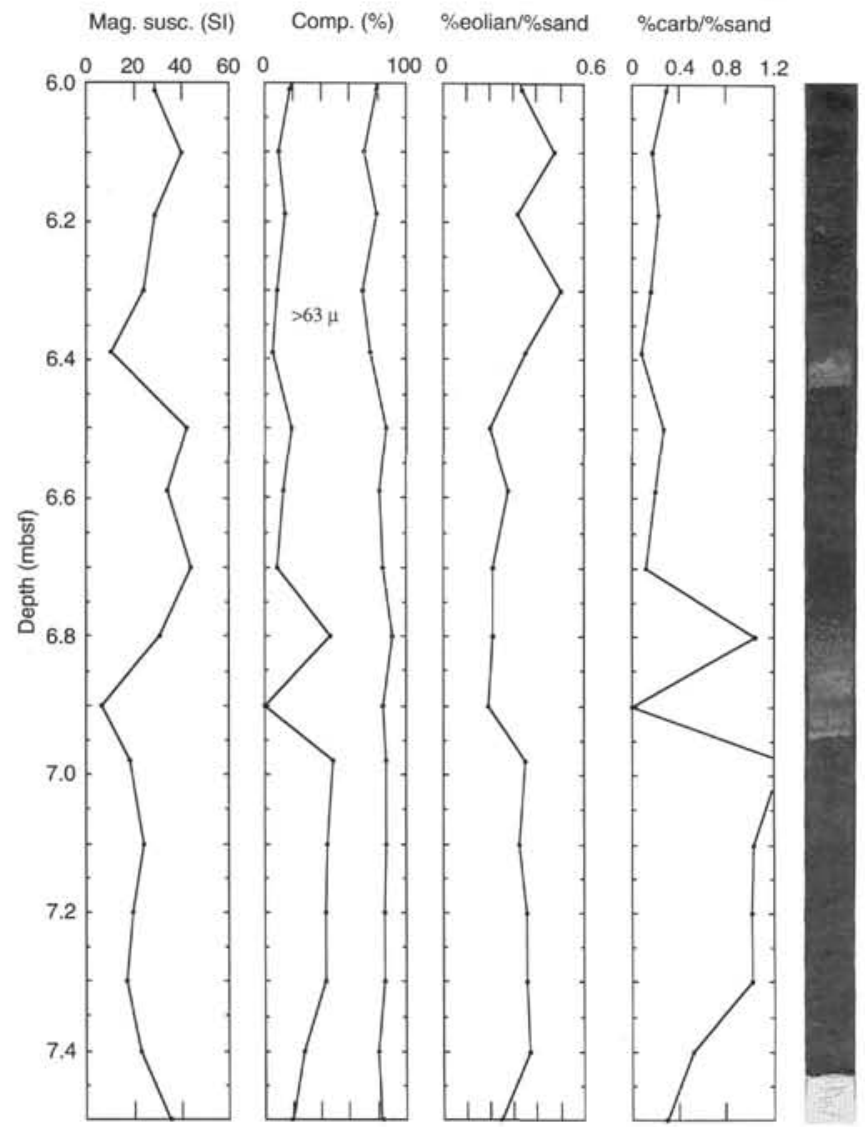

Figure 7. Comparisons between downhole sediment properties and the core photograph for Section 144-880A-1H-5 (6.0-7.5 mbsf).

genic material at $16.47 \mathrm{mbsf}$ may indicate a layer of volcanic ash. A high percentage $(27 \%)$ of fine-grained lithogenic material at $\sim 17.57$ mbsf may indicate another ash layer. The overlying, light-colored, low-susceptibility interval may indicate that ash particles are disseminated from $\sim 17.6$ to 17.3 mbsf.

It is clear from an examination of these core-section photographs and compositional plots that changes in sediment color are related to variations in lithologic composition and rock-magnetic parameters. It is possible to identify the position of volcanic ash layers by decreased levels of susceptibility and increased amounts of chemically extracted lithogenic (including volcaniclastic) material.

Although further work is necessary to determine the age and geochemical signature of specific ash events at this site, there seems to be the opportunity to develop an integrated stratigraphy of magnetic polarity reversals, ash events, and biostratigraphic datums for use in future paleoceanographic investigations.

\section{SUMMARY AND CONCLUSIONS}

Hole $880 \mathrm{~A}$ preserves a late Pliocene through Pleistocene record of pelagic biogenous, terrigenous, and volcaniclastic sediment accumulation near a convergent margin setting along southeastern Japan. The 18.4-m sequence from Hole $880 \mathrm{~A}$ exhibits diverse changes in sediment color and variations in lithologic composition and rockmagnetic properties. This study has shown the potential for identifying volcanic ash layers by their low values of magnetic susceptibility and increased weight percentages of (extracted) fine-grained lithogenic material. The systematic use of rock-magnetic measurements and ratios of parameters (e.g., frequency-dependent susceptibility) may, in future studies, provide a useful tool for identifying changes in the relative composition and grain size of magnetic mineral assem-

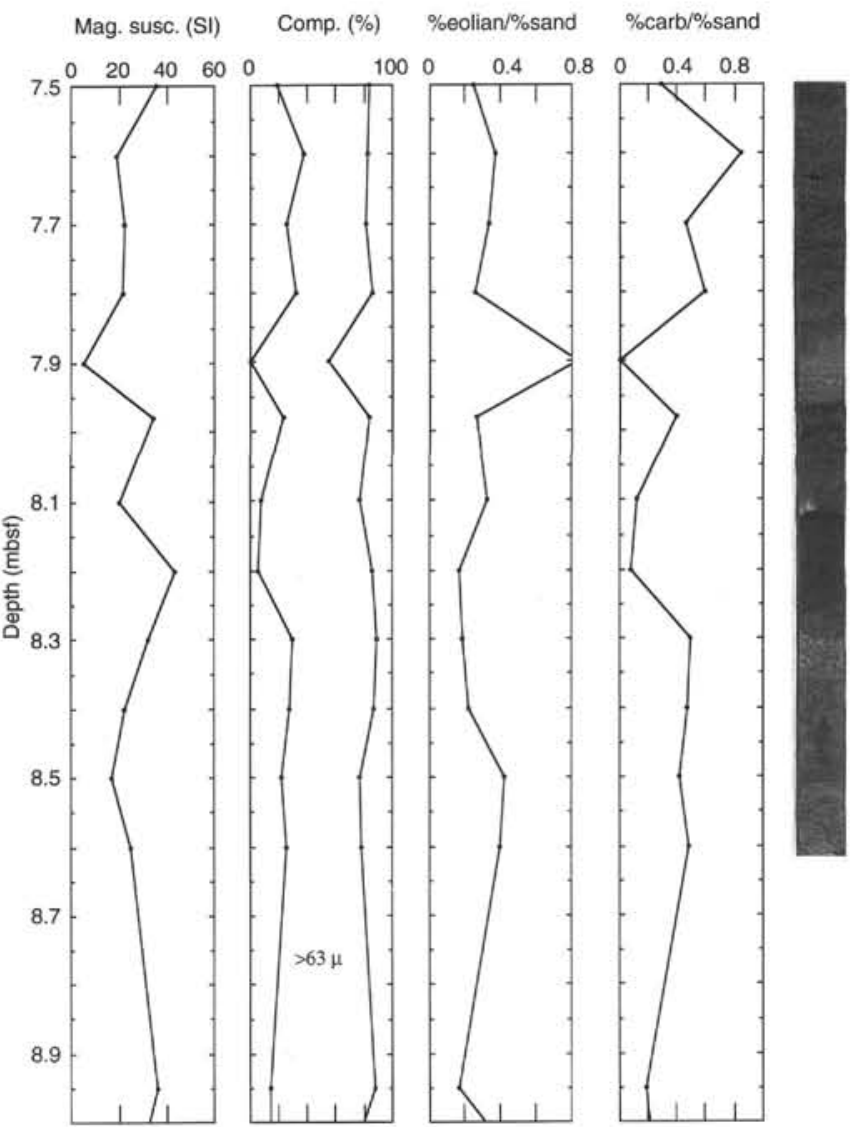

Figure 8. Comparisons between downhole sediment properties and the core photograph for Section 144-880A-1H-6 (7.5-9.0 mbsf).

blages preserved in Hole $880 \mathrm{~A}$; however, more research is needed to determine the source of these variations.

The preservation of both frequent volcanic ash layers and wellpreserved calcareous nannofossils in Hole 880A provides a reasonable opportunity to develop a high-resolution Quaternary stratigraphy for this site in the northwest Pacific Ocean. The present investigation serves as a pilot study for further analyses of these cores.

\section{ACKNOWLEDGMENTS}

This research was supported by a grant from JOI-USSAC and a post-doctoral fellowship to the primary author under the Canadian JGOFS Program. The authors thank Janet Haggerty and Isabella Premoli Silva for their enthusiastic support of this research, and the technicians at the ODP Gulf Coast Repository for their assistance with shore-based sample selection. The authors also thank Elisabetta Erba and the Leg 144 Scientific Party for discussion and cooperation relating to this study. Tanya Shank of TAMU provided assistance with data collection.

\section{REFERENCES}

Bloemendal, J., King, J.W., Hunt, A., deMenocal, P.B., and Hayashida, A., 1993. Origin of the sedimentary magnetic record at Ocean Drilling Program sites on the Owen Ridge, western Arabian Sea. J. Geophys. Res., 98:4199-4219.

\footnotetext{
- Abbreviations for names of organizations and publications in ODP reference lists follow the style given in Chemical Abstracts Service Source Index (published by American Chemical Society).
} 
Bloemendal, J., Lamb, B., and King, J., 1988. Paleoenvironmental implications of rock-magnetic properties of late Quaternary sediment cores from the eastern equatorial Atlantic. Paleoceanography, 3:61-87.

Clemens, S.C., and Prell, W.L., 1990. Late Pleistocene variability of Arabian Sea summer monsoon winds and continental aridity: eolian records from the lithogenic component of deep-sea sediments. Paleoceanography, 5:109-145.

Doh, S.-J., King, J.W., and Leinen, M., 1988. A rock-magnetic study of giant piston core LL4-GPC3 from the central North Pacific and its paleoceanographic implications. Paleoceanography, 3:89-111.

Maher, B.A., 1986. Characterization of soils by mineral magnetic measurements. Phys. Earth Planet. Inter., 42:76-92.

1988. Magnetic properties of some synthetic sub-micron magnetites. Geophys. J. (Oxford), 94:83-96.

Nakanishi, M., Tamaki, K., and Kobayashi, K., 1992. Magnetic anomaly lineations from Late Jurassic to Early Cretaceous in the west-central Pacific Ocean. Geophys. J. Int., 109:701-719.

Ozima, M., Honda, M., and Saito, K., 1977. ${ }^{40} \mathrm{Ar} /{ }^{39} \mathrm{Ar}$ ages of guyots in the western Pacific and discussion of their evolution. Geophys. J. R. Astron. Soc., 51:475-485.

Premoli Silva, I., Haggerty, J., Rack, F., et al., 1993. Proc. ODP, Init. Repts., 144: College Station, TX (Ocean Drilling Program).

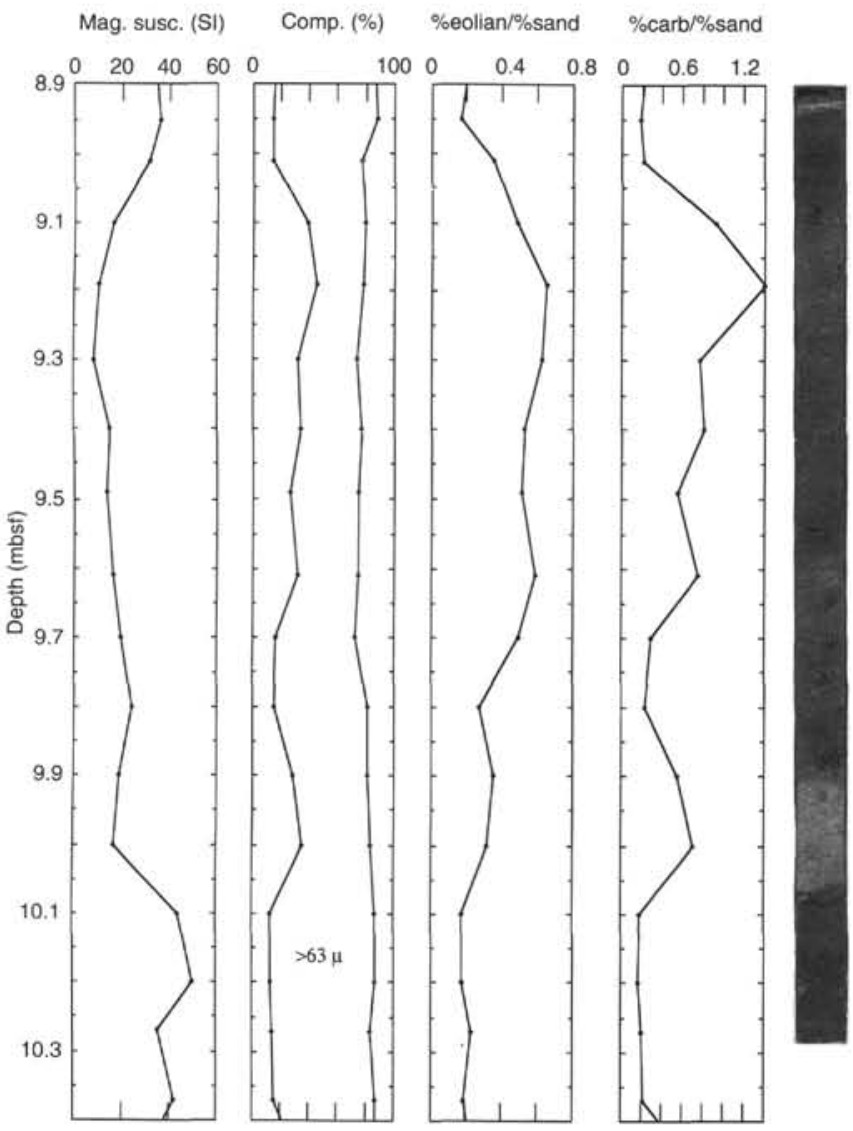

Figure 9. Comparisons between downhole sediment properties and the core photograph for Section 144-880A-2H-1 (8.9-10.4 mbsf).
Rea, D.K., and Janecek, T.R., 1981. Mass-accumulation rates of the nonauthigenic inorganic crystalline (eolian) component of deep-sea sediments from the western mid-Pacific Mountains, Deep Sea Drilling Project Site 463. In Theide, J., Vallier, T.L., et al., Init. Repts. DSDP, 62: Washington (U.S. Govt. Printing Office), 653-659.

Robinson, S.G., 1986. The late Pleistocene paleoclimatic record of North Atlantic deep-sea sediments revealed by mineral-magnetic measurements. Phys. Earth Planet. Inter., 42:22-47.

Thompson, R., and Oldfield, F., 1986. Environmental Magnetism: Boston (Allen and Unwin).

van Waasbergen, R.J., and Winterer, E.L., 1993. Summit geomorphology of Western Pacific guyots. In Pringle, M.S., Sager, W.W., Sliter, W.V., and Stein, S. (Eds.), The Mesozoic Pacific: Geology, Tectonics, and Volcanism. Geophys. Monogr., Am. Geophys. Union, 77:335-366.

Vogt, P.R., and Smoot, N.C., 1984. The Geisha Guyots: multibeam bathymetry and morphometric interpretation. J. Geophys. Res., 89:11085-11107.

Date of initial receipt: 1 February 1994

Date of acceptance: 28 July 1994

Ms 144SR-044

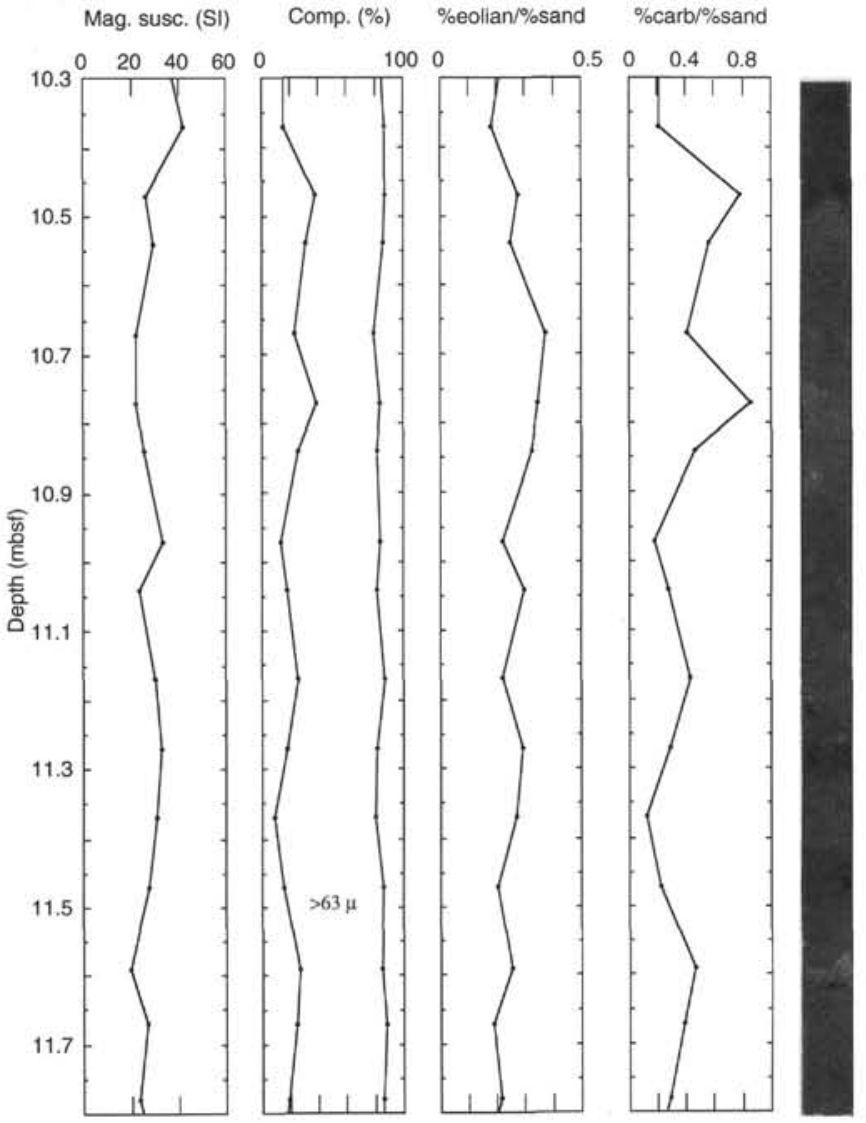

Figure 10. Comparisons between downhole sediment properties and the core photograph for Section 144-880A-2H-2 (10.4-11.8 mbsf). 


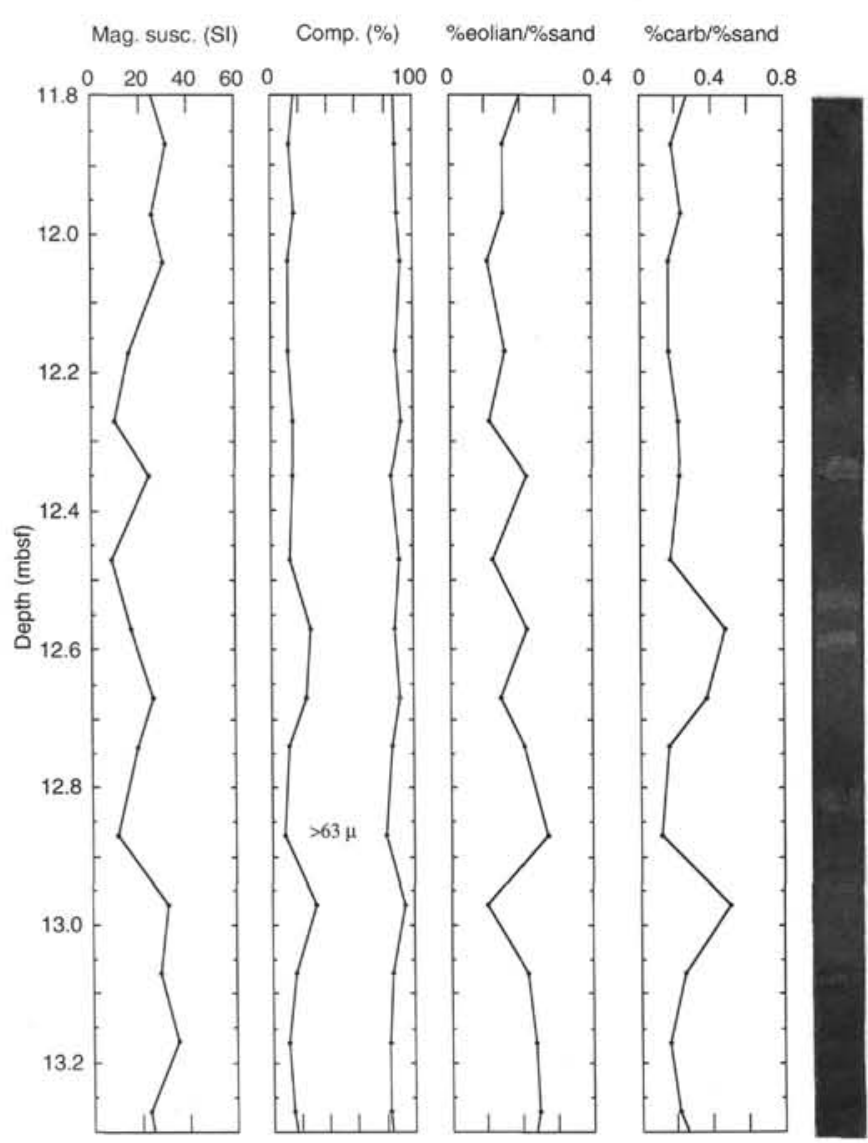

Figure 11. Comparisons between downhole sediment properties and the core photograph for Section 144-880A-2H-3 (11.8-13.3 mbsf).

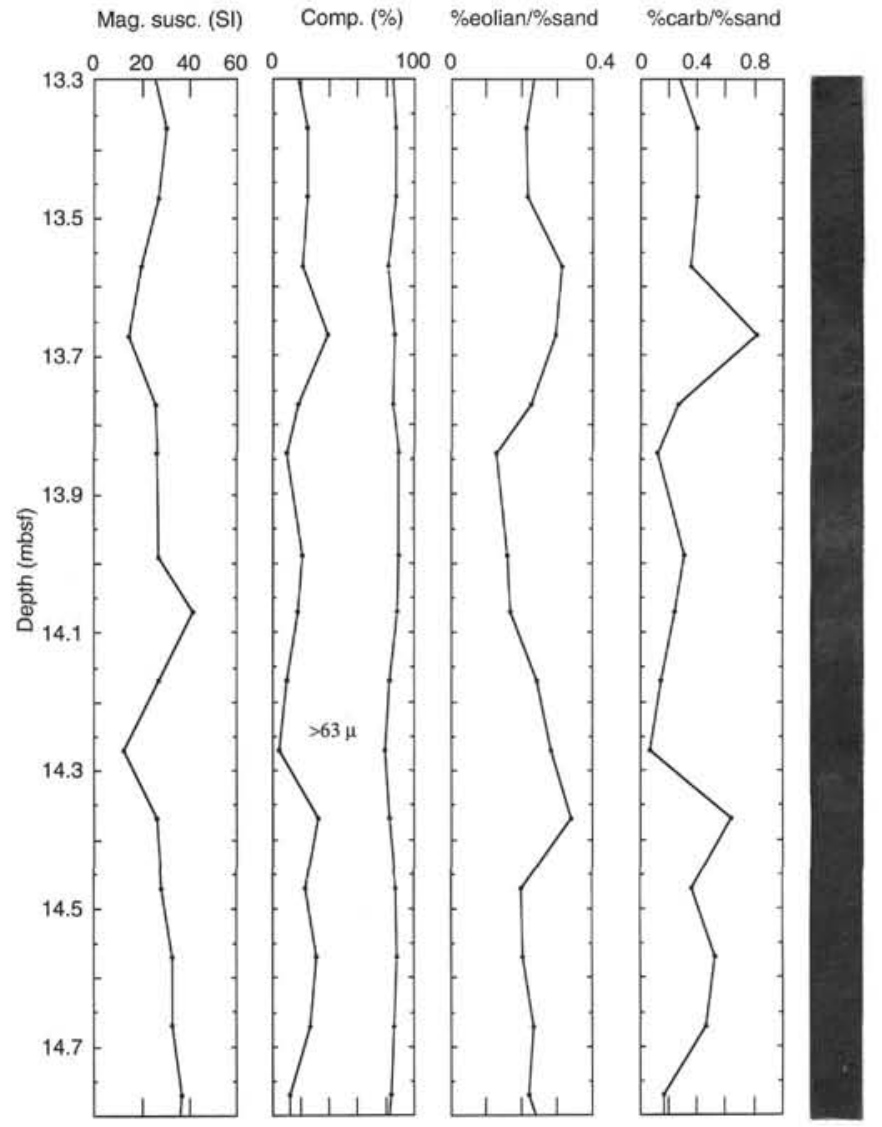

Figure 12. Comparisons between downhole sediment properties and the core photograph for Section 144-880A-2H-4 (13.3-14.8 mbsf). 
DATA REPORT —

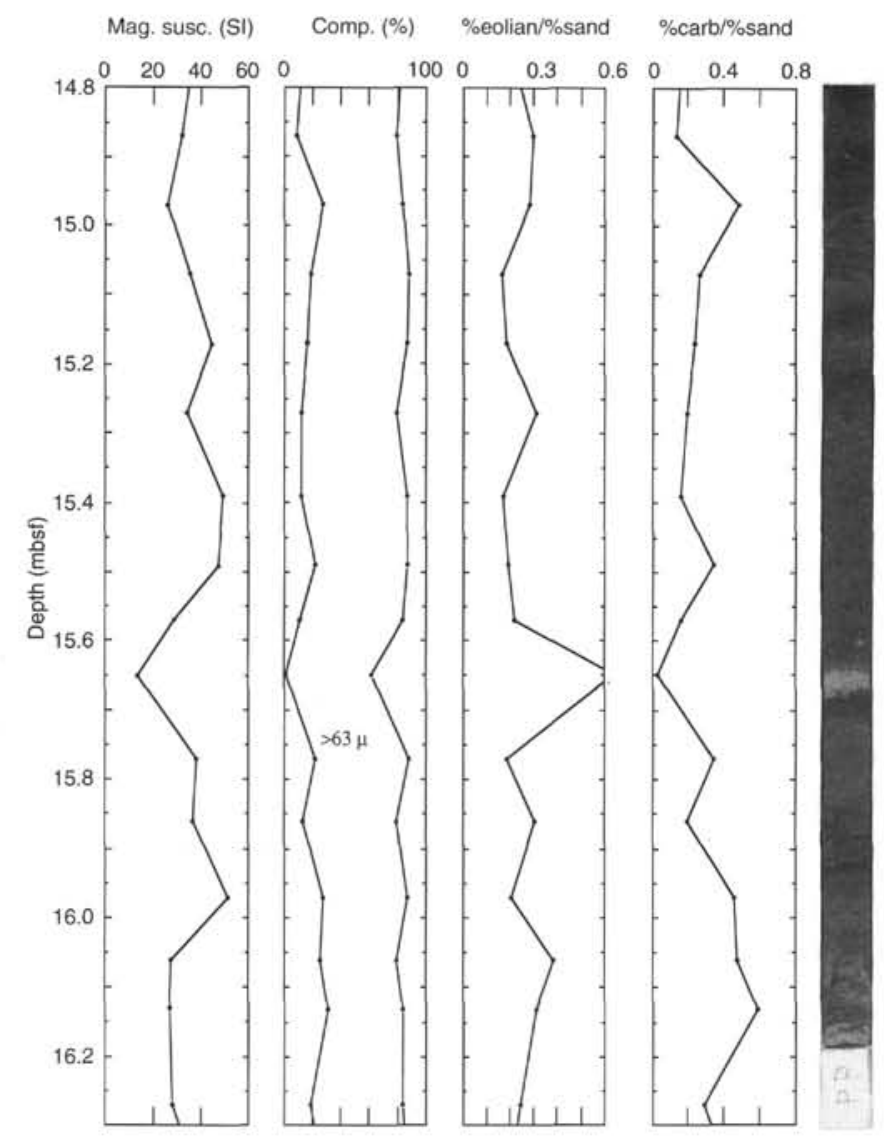

Figure 13. Comparisons between downhole sediment properties and the core photograph for Section 144-880A-2H-5 (14.8-16.3 mbsf).

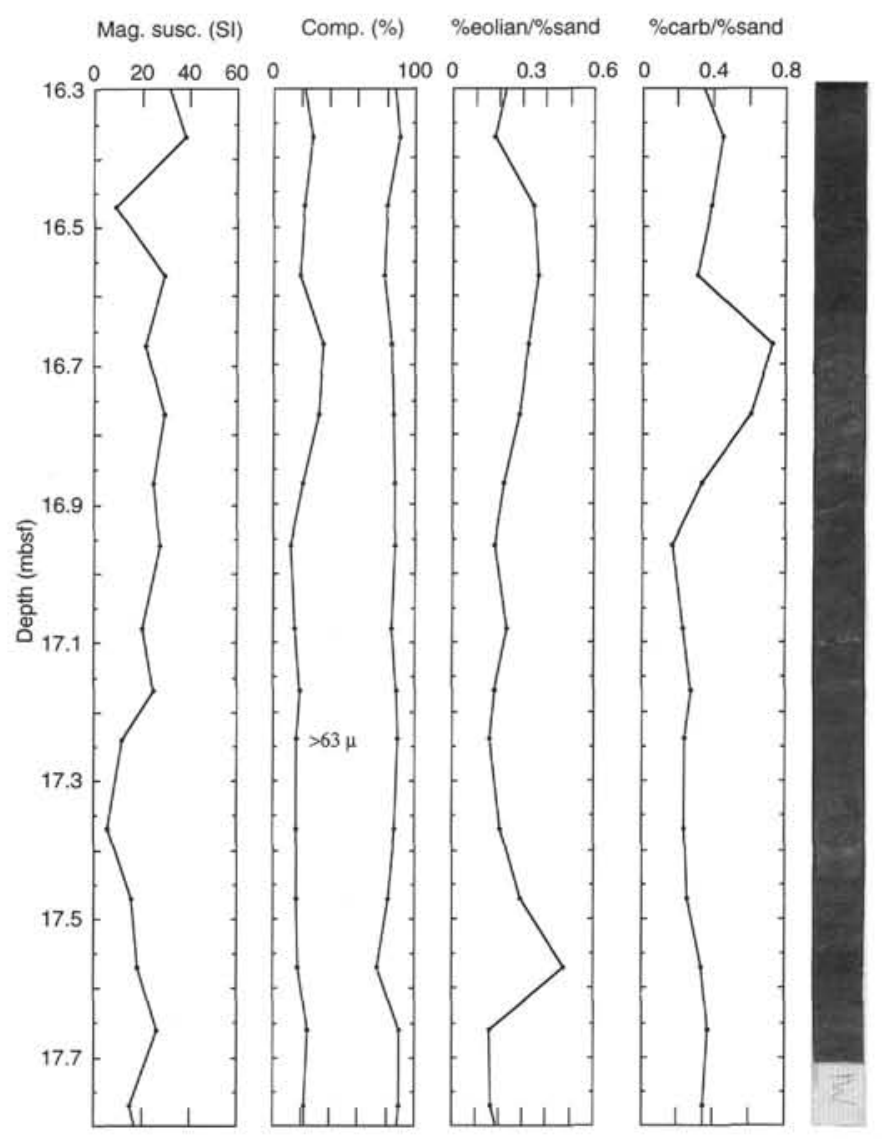

Figure 14. Comparisons between downhole sediment properties and the core photograph for Section 144-880A-2H-6 (16.3-17.8 mbsf).

984 